\title{
Mediation of nitrogen by post-disturbance shelf communities experiencing organic matter enrichment
}

\author{
Marija Sciberras (i) $\cdot$ Karen Tait • Guillaume Brochain · Jan G. Hiddink • \\ Rachel Hale • Jasmin A. Godbold • Martin Solan
}

Received: 31 October 2016/Accepted: 15 August 2017/Published online: 29 August 2017

(C) The Author(s) 2017. This article is an open access publication

\begin{abstract}
Microbes and benthic macro-invertebrates interact in sediments to play a major role in the biogeochemical cycling of organic matter, but the extent to which their contributions are modified following natural and anthropogenic changes has received little attention. Here, we investigate how nitrogen transformations, ascertained from changes in archaeal and bacterial $\mathrm{N}$-cycling microbes and water macronutrient concentrations $\left(\left[\mathrm{NH}_{4}-\mathrm{N}\right],\left[\mathrm{NO}_{2}-\mathrm{N}\right]\right.$, $\left.\left[\mathrm{NO}_{3}-\mathrm{N}\right]\right)$, in sand and sandy mud sediments differ when macrofaunal communities that have previously experienced contrasting levels of chronic fishing disturbance are exposed to organic matter enrichment.
\end{abstract}

Responsible Editor: Leila J. Hamdan.

Electronic supplementary material The online version of this article (doi:10.1007/s10533-017-0370-5) contains supplementary material, which is available to authorized users.

M. Sciberras $(\bowtie) \cdot$ J. G. Hiddink

School of Ocean Sciences, Bangor University, Askew St, Menai Bridge, Anglesey LL59 5AB, UK

e-mail: m.sciberras@bangor.ac.uk

K. Tait · G. Brochain

Plymouth Marine Laboratory, Prospect Place, The Hoe,

Plymouth PL1 3DH, UK

R. Hale $\cdot$ J. A. Godbold · M. Solan

Ocean and Earth Science, National Oceanography Centre

Southampton, University of Southampton Waterfront

Campus, European Way, Southampton SO14 3ZH, UK
We find that differences in macrofaunal community structure related to differences in fishing activity affect the capacity of the macrofauna to mediate microbial nitrogen cycling in sand, but not in sandy mud environments. Whilst we found no evidence for a change in ammonia oxidiser community structure, we did find an increase in archaeal and bacterial denitrifier (AnirKa, nirS) and anammox (hzo) transcripts in macrofaunal communities characterized by higher ratios of suspension to deposit feeders, and a lower density but higher biomass of sediment-reworking fauna. Our findings suggest that nitrogen transformation in shelf sandy sediments is dependent on the stimulation of specific nitrogen cycling pathways that are associated with differences in the composition and context-dependent expression of the functional traits that belong to the resident bioturbating macrofauna community.

Keywords Ammonia-oxidisers - Bioturbation · Bottom fishing $\cdot$ Denitrification $\cdot$ Ecosystem functioning - Microbial-invertebrate interactions . Nitrogen cycling

\section{Introduction}

Marine soft-sediments cover almost $70 \%$ of the earth's surface and play a fundamental role in the remineralization of organic carbon and nutrient cycling 
(Olsgard et al. 2008). According to current nitrogen budgets, it is estimated that up to $80 \%$ of the nitrogen needed by primary producers in shallow shelf seas is provided by benthic remineralization processes, primarily driven by microbial organisms that occur across the oxic/anoxic interface near the sediment surface (Dale and Prego 2002; Zehr and Kudela 2011). With $23 \%$ of the global human population concentrated in coastal areas, at an average density nearly 3 times higher than the global average (Small and Nicholls 2003) and an increase in demand in food production, coastal and shelf sea benthic systems are increasingly vulnerable to anthropogenic activities such as fishing and are at higher risk of eutrophication following excessive nutrient input. Any change in the balance and distribution of reactive nitrogen (e.g. ammonium $\mathrm{NH}_{4}{ }^{+}$, nitrite $\mathrm{NO}_{2}{ }^{-}$and nitrate $\mathrm{NO}_{3}{ }^{-}$), oxygen, and organic substrates are likely to have profound consequences for nitrification, denitrification and anaerobic ammonium oxidation (anammox) that regulate coastal nitrogen budgets (Laverock et al. 2011).

Bottom fishing that uses demersal gear such as trawls and dredges to catch fish, crustaceans and bivalves living in, on or in association with the seabed, exerts a number of pressures on benthic systems that might influence sedimentary nutrient generation and budgets (Pilskaln et al. 1998; Olsgard et al. 2008). Physical processes such as sediment resuspension and sediment mixing caused by trawling alter grain size distribution, sediment sorting and porosity (Trimmer et al. 2005) that may in turn disrupt nitrification and denitrification processes (Rysgaard et al. 1994; Kitidis et al. 2017) through changes in oxygen penetration depth within the sediment (Warnken et al. 2003) and burial of organic matter to anoxic layers before aerobic remineralisation can take place (Mayer et al. 1991; Pilskaln et al. 1998). The combination of removal of surficial sediments and mixing or burial of organic matter to depth (Duplisea et al. 2001; Warnken et al. 2003) occurs on different time-scales to those of alterations in community structure; changes in porewater and bottom water nutrient levels due to sediment resuspension return to pre-trawling levels within minutes to hours (e.g. Falcão et al. 2003; Trimmer et al. 2005; Goldberg et al. 2014), whilst microbial assemblage structure and biomass in the surficial sediment layers (upper $1 \mathrm{~cm}$ ) return to pre-disturbance levels within days (Fiordelmondo et al. 2003) to
4-6 months (Watling et al. 2001). In contrast, macrofaunal communities can take up to 4-5 years to recover (Kaiser et al. 2006; Lambert et al. 2014). Over extended and repeated periods of fishing activity, changes in the functional composition of invertebrate communities can have a disproportionate influence on nutrient cycling through changes in the bioturbation potential of the benthic community (Duplisea et al. 2001; Widdicombe et al. 2004). The active redistribution of particles (bioturbation) and fluids (bioirrigation) by infaunal macro-invertebrates, such as bivalves, polychaetes and crustaceans, directly contributes to the spatial and temporal heterogeneity of oxic and anoxic zones (Bertics and Ziebis 2009), organic matter availability (Levin et al. 1997) and the distribution of metabolic electron acceptors (Fanjul et al. 2007) that are important in controlling microbial process rates (Gilbertson et al. 2012; Laverock et al. 2014). The close association between the macrobenthic invertebrate community composition and microbial activity suggests that a reduction in bioturbation potential of the benthic community ensuing from the loss or change in relative composition of invertebrate species associated with bottom fishing will lead to changes in microbial-mediated processes such as nitrification, denitrification and anammox. Relative to the direct physical effects of fishing gear on sediment and faunal structure, however, the extent to which microbial-invertebrate coupling is modified and affects nutrient budgets in post-disturbance communities has received little attention.

Fluctuations in organic matter input following events such as algal blooms or run-off associated with high intensity precipitation, also have a prominent influence on benthic invertebrate fauna (van Oevelen et al. 2009; Zhang et al. 2015) and microbial community composition (Franco et al. 2007; Mayor et al. 2012; Tait et al. 2015). Benthic communities may be affected positively as food becomes available to both invertebrate grazers and bacteria and archaea, or negatively because an excess of organic matter may result in deoxygenation of the sediment (Quijón et al. 2008; Mayor et al. 2012). Zhang et al. (2015) observed a doubling effect on macrofaunal production and biomass during a spring algal bloom relative to the end of the bloom in the Western English Channel. Increases in organic matter have also been related to increases in bacterial biomass (Tait et al. 2015), in bacterial growth efficiency and carbon mineralization 
(Mayor et al. 2012), leading to subsequent increases in $\mathrm{NH}_{4}{ }^{+}$sediment flux, oxygen consumption and denitrification (Caffrey et al. 1993; Conley and Johnstone 1995). Whether post-disturbance benthic communities retain the assimilative capacity to 'process' systemlevel nutrient inputs has not been adequately evaluated.

Here, we investigate how post-disturbance macroinvertebrate communities affect archaeal and bacterial $\mathrm{N}$-cycling community activity and composition and associated nutrient concentrations. We compare communities (macro-invertebrate and microbial) from sites that have been exposed to different levels of chronic fishing activity, on the a priori assumption that benthic macro-invertebrate communities would be restructured by chronic physical disturbance and that the adjusted post-disturbance community would persist long after the perturbation event (Kaiser et al. 2006). Further, we examine whether the effect of organic matter enrichment is sufficient to alter nitrogen dynamics by activating the microbial community. Our motivation was that the addition of organic matter would likely result in an increase in microbial activity, leading to increases in $\mathrm{NH}_{4}{ }^{+}$sediment flux, oxygen consumption and denitrification that might be sufficient to offset any negative biogeochemical effects related to faunal change associated with prior fishing activity. To widen the generalizability of our conclusions, we examine the effects of chronic fishing disturbance and organic matter enrichment on nitrogen cycling in different sediment types; a diffusion dominated community (sandy mud) and an advection dominated community (sand). We assume that the level of biogeochemical performance that is realized in either sediment type will depend at least in part on the structure and composition of the post-disturbance macro-invertebrate community, as the active redistribution of particles and fluids by the macrofauna disproportionately influences benthic fluxes and total benthic metabolism (Mermillod-Blondin et al. 2004; Mermillod-Blondin and Rosenberg 2006).

\section{Methods}

Sediment collection and experimental set-up

In order to investigate how the effects of organic matter enrichment (levels: Non-enriched and Enriched) and previous exposure to bottom fishing (levels: Low and High) affect macro-invertebrate activity and microbial transformations of nitrogen in sand (S) and in sandy mud (sM) communities, we collected and maintained intact sediment cores ( $\mathrm{n}=40, \quad 5$ cores per treatment; LWH, $20 \times 20 \times 12 \mathrm{~cm}$ ) with their associated fauna using a $0.1 \mathrm{~m}^{2}$ NIOZ (Netherlands Institute for Sea Research, Texel) corer from two fishing grounds in the Irish Sea. Sandy (S) sites were located off the east coast of the Isle of Man where scallop dredging for Pecten maximus and some otter trawling for Aequipecten opercularis occurs, whereas sand muddy (sM) sites were located off the coast of Cumbria, England, where otter trawling for Nephrops norvegicus and gadoid fish occurs (Table 1). Logistics such as available ship time for collecting and storage space in constant-temperature rooms for housing the mesocosms posed limitations on the number of withintreatment replicates for this study. We acknowledge that we used a relatively small number of replicates

Table 1 Summary of environmental characteristics and bottom fishing frequency of our study sites

\begin{tabular}{|c|c|c|c|c|c|c|c|c|}
\hline $\begin{array}{l}\text { Site } \\
\text { code }\end{array}$ & $\begin{array}{l}\text { Geographical } \\
\text { location (latitude, } \\
\text { longitude) }\end{array}$ & $\begin{array}{l}\text { Fishing frequency } \\
\text { (times fished per } \\
\text { annum) }\end{array}$ & $\begin{array}{l}\text { Depth } \\
\text { (m) }\end{array}$ & $\begin{array}{l}\text { Tide } \\
\text { stress } \\
\left(\mathrm{Nm}^{-2}\right)\end{array}$ & $\begin{array}{l}\text { Wave } \\
\text { stress } \\
\left(\mathrm{Nm}^{-2}\right)\end{array}$ & Sand $(\%)$ & Mud (\%) & $\begin{array}{l}\text { Organic } \\
\text { matter } \\
(\mathrm{mg})\end{array}$ \\
\hline $\begin{array}{l}\text { sM- } \\
\text { low }\end{array}$ & $54.15 \mathrm{~N},-3.63 \mathrm{~W}$ & 3.8 & 26.00 & 0.17 & 0.69 & $33.48 \pm 2.62$ & $66.48 \pm 2.62$ & $70 \pm 6.33$ \\
\hline $\begin{array}{l}\text { sM- } \\
\text { high }\end{array}$ & $54.26 \mathrm{~N},-3.73 \mathrm{~W}$ & 8.4 & 28.54 & 0.22 & 0.68 & $36.43 \pm 1.98$ & $63.55 \pm 1.99$ & $90 \pm 12.65$ \\
\hline S-low & $54.20 \mathrm{~N},-4.05 \mathrm{~W}$ & 0.25 & 19.80 & 0.17 & 1.00 & $99.51 \pm 0.38$ & $0.02 \pm 0.02$ & $40 \pm 6.33$ \\
\hline $\begin{array}{l}\text { S- } \\
\text { high }\end{array}$ & $54.26 \mathrm{~N},-4.19 \mathrm{~W}$ & 1.63 & 18.79 & 0.11 & 0.73 & $94.2 \pm 0.68$ & $4.7 \pm 0.53$ & $70 \pm 9.49$ \\
\hline
\end{tabular}

Values for percent sand, percent mud and organic matter content $(\mathrm{mg})$ are given as mean \pm SE $(n=10)$ 
and caution that $\mathrm{p}$-values close to a probability value of 0.05 should be interpreted with care; nonetheless we adopt a conservative approach and present marginal $(\mathrm{p}<0.075)$ findings that indicate possible trends. Within each fishing ground, sediment cores were collected from two sites of contrasting exposure to chronic fishing disturbance (Table 1). We categorized fishing activity at each site by calculating the number of times the site is swept by bottom fishing gear in a year $\left(\mathrm{km}^{2}\right.$ swept $\mathrm{km}^{-2}$ seabed year $\left.{ }^{-1}\right)$ using Vessel Monitoring System (VMS) records for UK registered vessel $>15 \mathrm{~m}$ over the 3 year period prior to our survey (further details in Sciberras et al. 2016). Since VMS is only mandatory for vessels over $15 \mathrm{~m}$ (EC 2003), the activity of vessels smaller than $15 \mathrm{~m}$, particularly those between 8 and $15 \mathrm{~m}$ is not represented. Therefore, estimates of fishing frequency may be underestimates of the actual fishing intensity, but as the spatial distribution of large and small trawlers are correlated, our measure of fishing frequency is a useful indicator of the relative fishing disturbance experienced by benthic communities at the sampled sites. Variation in habitat characteristics (e.g. sediment grain size composition, organic matter content, water depth, bottom temperature and tidal shear stress) among replicate cores collected from within each of the two sediment types was minimized to ensure that any observed differences reflected differences associated with changes in species composition due to fishing rather than environmental variability (Table 1, Electronic Supplementary Material (ESM) 1). Sediment grain size and organic matter content were determined for a separate sediment sample $(\varnothing=5 \mathrm{~cm}$, $5 \mathrm{~cm}$ deep) taken from each NIOZ core sample collected on-site. A combination of dry sieving (1-9.5 mm at $0.25 \varphi$ intervals) and laser diffraction techniques (Malvern 2000 particle sizer, range: 0.21-1003.44 $\mu \mathrm{m}$ ) were used to produce a complete particle size distribution. Organic matter content was estimated by mass loss on ignition of $\sim 5 \mathrm{~g}$ of dried sediment at $550{ }^{\circ} \mathrm{C}$ for $6 \mathrm{~h}$ (Holme and McIntyre 1984).

Each intact sediment core was transferred to a Perspex aquarium, overlaid by $\sim 20 \mathrm{~cm}(8 \mathrm{~L})$ of ambient seawater and incubated in the laboratory in the dark at constant temperature $\left(13{ }^{\circ} \mathrm{C}\right.$, approximating mean sea bottom temperature during the sampling period, 22-28th June 2015) for 1 month. The experimental period incorporated a 15 day acclimatization period prior to the addition of organic matter and a 15 day experimental period following the addition of organic matter. Enriched treatments $(\mathrm{n}=20)$ received $50 \mathrm{~mL}$ of the microalga Isochrysis galbana on day 16 (concentration of $\sim 22$ cells $\mu \mathrm{L}^{-1}$; based on field observations of chlorophyll- $a$ levels at $\sim 10 \mathrm{~m}$ depth for the central Celtic Sea during a typical spring algal bloom, pers. comm. Dr. Alex Poulton, National Oceanography Centre, Southampton). All aquaria were aerated by bubbling with filtered air for the duration of both the acclimatization and experimental periods.

Water nutrient, microbial and macro-invertebrate community analysis

A pre-filtered $(0.45 \mu \mathrm{m}$, NALGENE) water sample was collected from approximately mid-point of the overlying water column of each aquarium at the end of the experiment. Absolute concentrations of ammonium $\left[\mathrm{NH}_{4}-\mathrm{N}\right]$, nitrite $\left[\mathrm{NO}_{2}-\mathrm{N}\right]$ and nitrate $\left[\mathrm{NO}_{3}-\mathrm{N}\right]$ were quantified using colorimetric techniques and a segmented flow nutrient autoanalyser (Bran and Luebbe, Model AAIII).

To quantify abundance and activity of N-cycling associated microbes, sediment samples $(1 \mathrm{~mL})$ were collected from the top $1 \mathrm{~cm}$ of the sediment from each core at the end of the experiment and added to a LifeGuard Soil Preservation Solution (MoBio Laboratories, Inc., Carlsbad, California, USA) and stored at $-20{ }^{\circ} \mathrm{C}$ until further analysis. RNA and DNA were extracted from $0.4 \mathrm{~g}$ sediment samples using the RNA PowerSoil $^{\circledR}$ Total RNA Isolation Kit with the RNA PowerSoil $^{\circledR}$ DNA Elution Accessory Kit (MoBio Laboratories, Inc., Carlsbad, California, USA). Changes in the abundance of transcripts for key nitrogen cycling processes, nitrification (archaeal and bacterial ammonia monooxygenase, amoA that convert $\mathrm{NH}_{4}{ }^{+}$into $\mathrm{NO}_{2}{ }^{-}$and $\mathrm{NO}_{3}{ }^{-}$), denitrification (archaeal and bacterial nitrite reductase, nirK and nirS that convert $\mathrm{NO}_{3}{ }^{-}$into $\mathrm{N}_{2}$ ) and anammox (hydrazine oxidoreductase, hzo that converts $\mathrm{NO}_{2}{ }^{-}$and $\mathrm{NH}_{4}{ }^{+}$ into $\mathrm{N}_{2}$ ) were analysed via quantitative PCR (qPCR). In addition, as proxies for bacterial and archaeal abundance and activity, archaeal and bacterial $16 \mathrm{~S}$ rRNA genes and 16S RNA were also quantified. Terminal Restriction Fragment Length Polymorphism (T-RFLP) was used to compare the impact of fishing frequency and organic matter addition on the 
composition of total and active bacterial and archaeal communities. A detailed methodology for RNA, DNA and gene extraction, qPCR and associated primers and T-RFLP is provided in ESM2.

All invertebrates were recovered (500 $\mu \mathrm{m}$ sieve), fixed and preserved in $4 \%$ formaldehyde solution for subsequent identification to the highest practicable taxonomic resolution (mostly species) and the abundance and wet weight of each taxon was measured after blotting. Tube worms were weighed excluding tubes. The values of total biomass include fragments of organisms that could not be assigned to specific taxa.

\section{Statistical analysis}

Statistical analyses to examine the effects of fishing frequency and organic matter enrichment on benthic communities (macrofauna, microbial) and water nutrients were kept separate for sand and sandy mud, primarily because the fisheries under study at the two sediment types use different fishing gears and operate in distinct habitat types with taxonomically different communities and because the range of fishing frequency was not comparable between the two study locations (Table 1). At the sandy mud fishing ground, very low or no fishing sites were characterized by different habitat conditions (sediment composition, tide and wave stress) from sites where fishing occurred. Therefore, sampling from sites with fishing frequency comparable to that in sand for the low fishing frequency treatment would have biased our conclusions about the effects of fishing and enrichment in sandy mud. The terms 'low' and 'high' are therefore used in a relative sense.

Linear regression models (full factorial, independent nominal variables: fishing frequency $\mathrm{F}$, organic matter enrichment E) were fitted for the response variables for the invertebrate community (total invertebrate density, biomass and species richness, the ratio of suspension to deposit feeders), microbial community (abundance of bacterial and archaeal nitrifiers (AOB amoA, AOA amoA), denitrifiers (AnirKa, nirS), and anammox $(h z o))$ and associated concentrations of dissolved inorganic nitrogen $\left(\left[\mathrm{NH}_{4}-\mathrm{N}\right],\left[\mathrm{NO}_{2}-\mathrm{N}\right]\right.$ and $\left.\left[\mathrm{NO}_{3}-\mathrm{N}\right]\right)$. The ratio of suspension to deposit feeders was examined as an indicator of compositional and functional change, as high levels of suspension feeder mortality (relative to deposit feeders) in fished areas have been shown to reduce the benthic oxygen demand and result in higher rates of nitrification (Allen and Clarke 2007). Information on species feeding mode was obtained from the biological traits database generated from the BENTHIS project (Bolam et al. 2014, http://www.benthis.eu/en/benthis/ Results.htm, accessed 16 July 2016). Further, to assess whether the sediment reworking potential of the macro-invertebrate community differed among treatments, species were classified as epifauna (E), surficial modifiers (SM), biodiffusors (B), upwards/downwards conveyors $(\mathrm{C})$ and regenerator $(\mathrm{R})$ following Solan et al. (2004) and updated by Queiros et al. (2013). Epifaunal organisms include species that occur predominantly above the sediment-water interface whose activities are limited to the near-surface sediment. Surficial modifiers are organisms whose activities are mostly restricted to the uppermost few centimetres of the sediment, rarely venturing above the sedimentwater interface. Biodiffusors include organisms with activities that usually result in a constant and random local sediment biomixing over short distances (ca. $5 \mathrm{~cm}$ ). Conveyors include burrow-building species that are vertically oriented in the sediment typically feeding head-down (upward conveyors) or head-up (downward conveyors) at depth in the sediment. Regenerators are excavators that dig and continuously maintain burrows in the sediment and by doing so they mechanically transfer sediment from depth to the surface (Solan et al. 2004; Kristensen et al. 2012). Density and biomass was summed to obtain the total of each reworking mode. A linear regression model incorporating the independent terms mode of sediment reworking $\left(\mathrm{R}_{\mathrm{i}}\right)$, fishing frequency $(\mathrm{F})$, organic matter enrichment $(E)$, and their interactions, was fitted for total density and total biomass. A significant interaction term $\left(F: R_{i}, E: R_{i}\right.$ or $\left.F: E: R_{i}\right)$ would indicate that changes in total density or total biomass reflect differences in response across bioturbation groups that depend on fishing frequency and/or organic matter enrichment.

Where there was evidence of violation of homogeneity of variance, the data were analyzed using a generalised least squares (GLS) estimation procedure to allow the residual spread to vary with individual independent variables (Zuur et al. 2009). To determine the optimal variance structure, we compared the full linear regression models to the equivalent GLS models incorporating specific variance structures 
using Akaike information criteria (AIC) and by inspection of model residual patterns. The optimal fixed-effects structure was then obtained by applying a backward selection using the likelihood ratio test obtained by maximum-likelihood (ML) estimation. Following Zuur et al. (2009), the optimal model was estimated using REML estimation. Homogeneity of residuals was established through visual examination of plotted standardized residuals versus fitted values. All analyses were performed using the nlme package (v. 3.1, Bates et al. 2013) in the R statistical and programming environment ( $\mathrm{R}$ Development Core Team 2005). A summary of the linear regression models output is presented here, coefficient tables that indicate the direction and magnitude of differences among treatments are presented in supplementary material, ESM 3. Unless indicated differently, univariate results are expressed as mean \pm standard error.

Differences in macrofaunal and microbial community composition associated with different fishing frequency and organic matter enrichment treatments were examined using PERMANOVA (Permutational analysis of variance). The relative contribution of species to significant effects was identified using SIMPER (Similarity percentages). All PERMANOVA and SIMPER analyses were conducted in PRIMER-E (Version 7, http://www.primer-e. $\operatorname{com} /)$.

\section{Results}

Sandy sediments

Macro-invertebrate density ranged from 100 to 3700 ind. $\mathrm{m}^{-2}$, total biomass from 1 to $853.25 \mathrm{gWW} \mathrm{m}^{-2}$ and species richness from 3 to 22 , but were not affected by fishing frequency or organic matter enrichment (Models 1-3, Table 2). However, the ratio of suspension to desposit feeders (Model 4, Table 2; Fig. 1a) and overall macro-invertebrate composition (PERMANOVA, density: Pseudo-F $=6.79, \mathrm{p}=0.001$; biomass: Pseudo-F $=2.56, p=0.009$; nMDS Fig. $1 b$ ) were dependent on the frequency of fishing. The nMDS ordination for density and biomass data was very similar, therefore only that for density is presented in Fig. 1b. Deposit feeders such as the polychaete Lagis koreni and the echinoderms Leptosynapta inhaerens,
Echinocardium cordatum and Echinocyamus pusillus were more abundant than suspension feeders in communities that had previously experienced a low frequency of bottom fishing (density: deposit feeders $=635 \pm 155$ ind. $\mathrm{m}^{-2}$, suspension feeders $=$ $92.5 \pm 20$ ind. $\mathrm{m}^{-2}$ ), whereas suspension feeders such as Phoronis sp., Owenia fusiformis and Abra alba were more abundant in communities that had previously experienced a high frequency of bottom fishing (density: deposit feeders $=262.5$ \pm 70 ind. $\mathrm{m}^{-2}$, suspension feeders $=357.5 \pm$ 47.5 ind. $\mathrm{m}^{-2}$ ) (Table 3a). Compositional differences were largely associated with a higher density of echinoderms (in particular L. inhaerens, E. cordatum, juvenile asteroids and E. pusillus) at lower fishing frequency, and a higher density of polychaetes $(O$. fusiformis, Magelona spp., Sthenelais limicola, Ophelina acuminata and Chaetozone sp.) (SIMPER, Table 3a) and larger individuals of E. cordatum (34 g) and the bivalves Acanthocardia echinata (6 g), Chamelea striatula (3 g) and Thracia phaseolina $(1.4 \mathrm{~g})$ at the higher fishing frequency sites (SIMPER, Table $3 b)$.

Sediment reworking group density depended on the interactive effects of sediment reworking group identity and the frequency of fishing (Model 5, Table 2); biodiffusor (e.g. E. cordatum, Glycera oxycephala) and conveyor species (e.g. L. koreni, T. phaseolina, Spiophanes bombyx) were more abundant after a low frequency of fishing (density: $492.5 \pm 133.28$ and $430 \pm 172.92$ ind. $\mathrm{m}^{-2}$, respectively) than they were after a high frequency of fishing (density: $180 \pm 80.78$ and $197.5 \pm 42.89$ ind. $\mathrm{m}^{-2}$, respectively) (Fig. 2a). Sediment reworking group biomass, however, was dependent on the independent effects (Model 6, Table 2) of organic matter enrichment (Fig. 2b) and sediment reworking group identity (Fig. 2c), with a greater biomass attributed to biodiffusors (e.g. E. cordatum, Sigalion mathilde, Lumbrineris sp.) and when sediments were enriched with organic matter.

T-RFLP profiling for archaeal and bacterial $16 \mathrm{~S}$ rRNA genes revealed significant differences in the total microbial community structure between communities that experienced low and high frequency of fishing activity (PERMANOVA: Archaea, Pseudo$\mathrm{F}=2.22, \quad \mathrm{p}=0.05 ; \quad$ Bacteria, $\quad$ Pseudo- $\mathrm{F}=4.03$, $\mathrm{p}=0.03$ ), but not among enriched and non-enriched treatments (Archaea, Pseudo-F $=0.66, \mathrm{p}=0.61$; 
Table 2 Linear regression models to examine the effects of fishing frequency and enrichment (full factorial, $\mathrm{F} \times \mathrm{E}$ ) in sand $(S)$, for macro-invertebrate community (Models 1-4: invertebrate density, biomass and species richness, the ratio of suspension to deposit feeders), sediment reworking groups $\left(\mathrm{R}_{\mathrm{i}}\right.$, reworking group density and biomass, Models 5-6), microbial community (Models 7-12: abundance of bacterial and archaeal denitrifiers (AnirKa, nirS), anammox (hzo), archaeal and bacterial nitrifiers (AOA $a m o A, \mathrm{AOB} a m o A$ ) and ratio of bacterial and archaeal amoA transcripts) and associated levels of dissolved inorganic nitrogen (Models 13-15: $\left[\mathrm{NO}_{2}-\mathrm{N}\right]$, $\left.\left[\mathrm{NO}_{3}-\mathrm{N}\right],\left[\mathrm{NH}_{4}-\mathrm{N}\right]\right)$

Sediment type: SAND (S)

\begin{tabular}{|c|c|c|c|c|c|c|c|}
\hline \multicolumn{8}{|c|}{ Macro-invertebrate community (Initial linear model: response variable $\sim \mathrm{F} \times \mathrm{E}$ ) } \\
\hline $\begin{array}{l}\text { Model } \\
\text { ID }\end{array}$ & Model & Response variable & $\begin{array}{l}\text { Fishing frequency } \\
\text { (F) }\end{array}$ & $\begin{array}{l}\text { Enrichment } \\
\text { (E) }\end{array}$ & $\begin{array}{l}\text { Interaction } \\
(\mathrm{F}: \mathrm{E})\end{array}$ & Intercept only & $\begin{array}{l}\text { Variance- } \\
\text { covariate }\end{array}$ \\
\hline 1 & GLS & $\begin{array}{l}\text { Macro-invertebrate } \\
\text { density }\end{array}$ & & & & $\begin{array}{l}\mathrm{L}=2.54, \mathrm{df}=1 \\
\mathrm{p}=0.11\end{array}$ & $\mathrm{E}$ \\
\hline 2 & GLS & $\begin{array}{l}\text { Macro-invertebrate } \\
\text { biomass }\end{array}$ & & & & $\begin{array}{l}\mathrm{L}=3.37, \mathrm{df}=1 \\
\mathrm{p}=0.07\end{array}$ & $\mathrm{E} \times \mathrm{F}$ \\
\hline 3 & GLS & Species richness & & & & $\begin{array}{l}\mathrm{L}=1.32, \mathrm{df}=1 \\
\mathrm{p}=0.25\end{array}$ & $\mathrm{E}$ \\
\hline 4 & GLS & $\begin{array}{l}\text { suspension: deposit } \\
\text { feeders ratio }\end{array}$ & $\begin{array}{l}\mathrm{L}=17.07, \mathrm{df}=1 \\
\mathrm{p}<0.001\end{array}$ & & & & $\mathrm{~F}$ \\
\hline
\end{tabular}

Sediment reworking groups (initial linear model: response variable $\sim \mathrm{F} \times \mathrm{E} \times \mathrm{Ri}$ )

\begin{tabular}{|c|c|c|c|c|c|c|c|c|c|}
\hline $\begin{array}{l}\text { Model } \\
\text { ID }\end{array}$ & Model & $\begin{array}{l}\text { Response } \\
\text { variable }\end{array}$ & $\begin{array}{l}\text { Fishing } \\
\text { frequency } \\
\text { (F) }\end{array}$ & Enrichment (E) & $\begin{array}{l}\text { Reworking mode } \\
\text { (Ri) }\end{array}$ & $F: E$ & $\mathrm{~F}: \mathrm{Ri}$ & $\begin{array}{l}\text { Intercept } \\
\text { only }\end{array}$ & $\begin{array}{l}\text { Variance- } \\
\text { covariate }\end{array}$ \\
\hline 5 & GLS & Ri density & & & & & $\begin{array}{c}\mathrm{L}=15.92 \\
\mathrm{df}=4 \\
\mathrm{p}=0.003\end{array}$ & & $\mathrm{Ri} \times \mathrm{F}$ \\
\hline 6 & GLS & $\begin{array}{l}\mathrm{Ri} \\
\text { biomass }\end{array}$ & & $\begin{array}{c}\mathrm{L}=4.09 \\
\mathrm{df}=1 \\
\mathrm{p}=0.04\end{array}$ & $\begin{array}{c}\mathrm{L}=27.05 \\
\mathrm{df}=4 \\
\mathrm{p}<0.0001\end{array}$ & & & & $\mathrm{Ri} \times \mathrm{F}$ \\
\hline
\end{tabular}

Abundance of active N-cycling associated microbes (Initial linear model: Response variable $\sim \mathrm{F} \times \mathrm{E}$ )

\begin{tabular}{|c|c|c|c|c|c|c|c|}
\hline $\begin{array}{l}\text { Model } \\
\text { ID }\end{array}$ & Model & $\begin{array}{l}\text { Response } \\
\text { variable }\end{array}$ & $\begin{array}{l}\text { Fishing frequency } \\
\text { (F) }\end{array}$ & Enrichment (E) & $\begin{array}{l}\text { Interaction } \\
(\mathrm{F}: \mathrm{E})\end{array}$ & Intercept only & $\begin{array}{l}\text { Variance- } \\
\text { covariate }\end{array}$ \\
\hline 7 & GLS & $\operatorname{nir} S$ & $\begin{array}{l}\mathrm{L}=3.63, \mathrm{df}=1 \\
\mathrm{p}=0.05\end{array}$ & $\begin{array}{l}\mathrm{L}=11.26, \mathrm{df}=1 \\
\mathrm{p}<0.001\end{array}$ & & & $\mathrm{~F}$ \\
\hline 8 & GLS & AnirKa & $\begin{array}{l}\mathrm{L}=6.41, \mathrm{df}=1 \\
\mathrm{p}=0.01\end{array}$ & & & & $E \times F$ \\
\hline 9 & GLS & hzo & $\begin{array}{l}\mathrm{L}=6.59, \mathrm{df}=1 \\
\mathrm{p}=0.01\end{array}$ & & & & $\mathrm{~F}$ \\
\hline 10 & GLS & AOA $a m o A$ & & & & $\begin{array}{l}\mathrm{L}=1.25, \mathrm{df}=1 \\
\mathrm{p}=0.26\end{array}$ & $\mathrm{E}$ \\
\hline 11 & GLS & AOB $a m o A$ & & & & $\begin{array}{c}\mathrm{L}=2.50, \mathrm{df}=1 \\
\mathrm{p}=0.11\end{array}$ & $\mathrm{~F}$ \\
\hline 12 & GLS & $\begin{array}{l}\text { AOB:AOA } \\
\text { amoA ratio }\end{array}$ & & & & $\begin{array}{c}\mathrm{L}=3.28, \mathrm{df}=1 \\
\mathrm{p}=0.07\end{array}$ & $\mathrm{E}$ \\
\hline
\end{tabular}

Water nutrient concentration (Initial linear model: Response variable $\sim \mathrm{F} \times \mathrm{E}$ )

\begin{tabular}{|c|c|c|c|c|c|c|c|}
\hline $\begin{array}{l}\text { Model } \\
\text { ID }\end{array}$ & Model & $\begin{array}{l}\text { Response } \\
\text { variable }\end{array}$ & Fishing frequency $(\mathrm{F})$ & $\begin{array}{l}\text { Enrichment } \\
\text { (E) }\end{array}$ & $\begin{array}{l}\text { Interaction } \\
(\mathrm{F}: \mathrm{E})\end{array}$ & Intercept only & $\begin{array}{l}\text { Variance- } \\
\text { covariate }\end{array}$ \\
\hline 13 & GLS & {$\left[\mathrm{NO}_{2}-\mathrm{N}\right]$} & $\begin{array}{c}\mathrm{L}=5.99, \mathrm{df}=1 \\
\mathrm{p}=0.01\end{array}$ & & & & $\mathrm{~F}$ \\
\hline
\end{tabular}


Table 2 continued

\begin{tabular}{|c|c|c|c|c|c|c|c|}
\hline \multicolumn{8}{|c|}{ Water nutrient concentration (Initial linear model: Response variable $\sim \mathrm{F} \times \mathrm{E}$ ) } \\
\hline $\begin{array}{l}\text { Model } \\
\text { ID }\end{array}$ & Model & $\begin{array}{l}\text { Response } \\
\text { variable }\end{array}$ & Fishing frequency $(\mathrm{F})$ & $\begin{array}{l}\text { Enrichment } \\
\text { (E) }\end{array}$ & $\begin{array}{l}\text { Interaction } \\
(\mathrm{F}: \mathrm{E})\end{array}$ & Intercept only & $\begin{array}{l}\text { Variance- } \\
\text { covariate }\end{array}$ \\
\hline 14 & GLS & {$\left[\mathrm{NO}_{3}-\mathrm{N}\right]$} & $\begin{array}{l}\mathrm{L}=19.47, \mathrm{df}=1 \\
\mathrm{p}<0.0001\end{array}$ & & & & $\mathrm{~F} \times \mathrm{E}$ \\
\hline 15 & GLS & {$\left[\mathrm{NH}_{4}-\mathrm{N}\right]$} & & & & $\begin{array}{l}\mathrm{L}=1.12, \mathrm{df}=1 \\
\mathrm{p}=0.29\end{array}$ & $\mathrm{E} \times \mathrm{F}$ \\
\hline
\end{tabular}

The test statistic (L-ratio or $\mathrm{F}$ value), degrees of freedom (df) and probability value (p) are listed for marginal ( $\mathrm{p}<0.075)$ or significant $(\mathrm{p}<0.05)$ terms. Where all independent variables were found insignificant, we present the intercept only model. The class of variance-covariate used to specify different variances for each level of stratification within-group are also provided



(b)

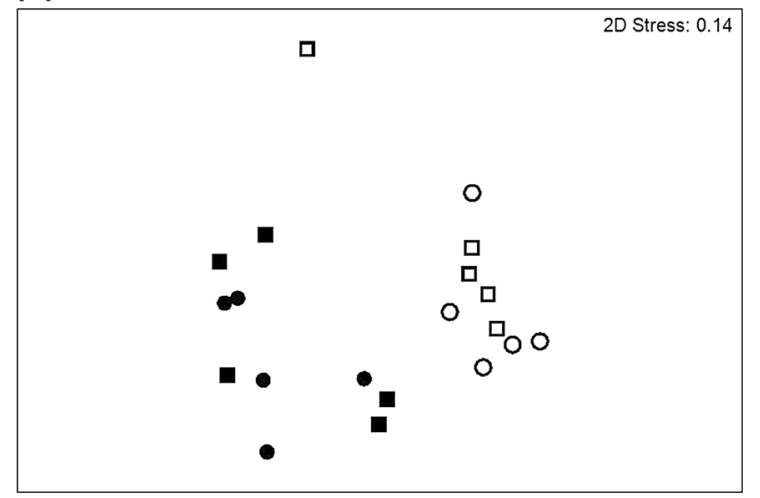

Fig. 1 The a independent effect of fishing frequency on the ratio of suspension:deposit feeders (mean $\pm \mathrm{SE}$ ) and $\mathbf{b}$ a nonmetric multidimensional scaling (nMDS) ordination of squareroot transformed Bray-Curtis resemblance matrix of macroinvertebrate density for communities in sand. In b contrasting levels of bottom fishing frequency (open symbol low, closed symbol high) and organic matter enrichment (circle nonenriched, square enriched) are presented, and the MDS dimensionality representation stress value is indicated

Bacteria, Pseudo-F $=0.92, \mathrm{p}=0.42$; ESM4 Fig. S2). The density of the metabolically active bacterial denitrifier (nirS) was dependent on the independent effects of fishing frequency (Fig. 3a) and organic matter enrichment (Fig. 3b), whilst both archaeal (AnirKa) denitrifiers (Fig. 3c) and anammox (hzo) hydrazine oxidoreductase transcripts (Fig. 3d) were dependent solely on the effect of fishing frequency (Models 7-9, Table 2). We found no evidence that the density of bacterial (AOB amoA) or archaeal (AOA amoA) ammonia oxidisers, or ammonia oxidiser community structure (AOB:AOA amoA ratio) were affected by the frequency of fishing or the level of organic matter enrichment (Models 10-12, Table 2).

For nutrients, we found that $\left[\mathrm{NO}_{2}-\mathrm{N}\right]$ and $\left[\mathrm{NO}_{3}-\mathrm{N}\right]$ were dependent on an independent effect of fishing frequency (Models 13-14, Table 2; Fig. 4), whilst $\left[\mathrm{NH}_{4}-\mathrm{N}\right]$ was not affected by fishing frequency or organic matter enrichment (Model 15, Table 2).

Sandy mud sediments

Relative to sandy sediments, total density (25450 ind. $\left.\mathrm{m}^{-2}\right)$, total biomass $\left(0.8-119.8 \mathrm{gWW} \mathrm{m}^{-2}\right)$ and species richness (1-9) were lower in sandy mud macro-invertebrate communities. Total macro-invertebrate density (Model 16, Table 4; Fig. 5a, b) and species richness (Model 17, Table 4; Fig. 5c, d) were dependent on the independent effects of fishing frequency and organic matter enrichment. Mean total density and species richness were highest for communities that had experienced a greater frequency of fishing (density: $227.5 \pm 40.5 \mathrm{~m}^{-2}$; species richness: $5.00 \pm 0.89$ core $^{-1}$ ) or organic matter enrichment (density: $200.00 \pm 30.51 \mathrm{~m}^{-2}$, species richness: $4.70 \pm 0.68$ core $\left.^{-1}\right)$. In contrast, we found no evidence of any macro-faunal response in terms of biomass (Model 18, Table 4). Similarly, the ratio of 
Table 3 The similarity percentage (SIMPER) dissimilarity tables (up to $90 \%$ of cumulative differences) of taxa (a) density and (b) biomass in sandy sites that experienced contrasting levels of fishing frequency (Levels: low and high fishing frequency)

\begin{tabular}{|c|c|c|c|c|c|c|}
\hline Species & Feeding mode & $\begin{array}{l}\text { Sediment reworking } \\
\text { functional type } \\
\text { (Queiros et al. 2013) }\end{array}$ & $\begin{array}{l}\text { Mobility } \\
\text { (Queiros } \\
\text { et al. 2013) }\end{array}$ & $\begin{array}{l}\text { Low fishing } \\
\text { frequency }\end{array}$ & $\begin{array}{l}\text { High fishing } \\
\text { frequency }\end{array}$ & $\begin{array}{l}\text { Contr. } \\
\text { diss. }(\%)\end{array}$ \\
\hline \multicolumn{7}{|c|}{ a. Groups tested: Taxon density between low and high fishing activity in sandy sediment } \\
\hline Lagis koreni & SubDF (MarLIN 2006) & $\mathrm{UC} / \mathrm{DC}$ & 1 & 3.59 & 1.56 & 8.81 \\
\hline Phoronis sp. & PSF, ASF (MarLIN 2006) & SM & 1 & 0.34 & 3.00 & 8.74 \\
\hline $\begin{array}{l}\text { Leptosynapta } \\
\text { inhaerens }\end{array}$ & $\begin{array}{l}\text { SubDF, Det (MarLIN } \\
\text { 2006) }\end{array}$ & SM & 3 & 2.88 & 0.00 & 8.39 \\
\hline $\begin{array}{l}\text { Echinocardium } \\
\text { cordatum }\end{array}$ & $\begin{array}{l}\text { SDF, SubDF (MarLIN } \\
\text { 2006) }\end{array}$ & B & 3 & 2.57 & 0.85 & 6.93 \\
\hline $\begin{array}{l}\text { Asteroid } \\
\text { juvenile }\end{array}$ & - & $\mathrm{E}$ & 3 & 1.46 & 0.00 & 4.29 \\
\hline $\begin{array}{l}\text { Owenia } \\
\text { fusiformis }\end{array}$ & $\begin{array}{l}\text { PSF, ASF, SDF, SubDF } \\
\text { (MarLIN 2006) }\end{array}$ & SM & 1 & 0.20 & 1.11 & 3.36 \\
\hline Magelona sp. & $\mathrm{SDF}^{\mathrm{a}}$ & SM & 2 & 0.14 & 0.73 & 2.64 \\
\hline $\begin{array}{l}\text { Glycera } \\
\text { oxycephala }\end{array}$ & Pred, Scav (MarLIN 2006) & B & 3 & 0.94 & 0.20 & 2.60 \\
\hline $\begin{array}{l}\text { Echinocyamus } \\
\text { pusillus }\end{array}$ & $\begin{array}{l}\text { SDF, SubDF (MarLIN } \\
\text { 2006) }\end{array}$ & $\mathrm{SM}$ & 3 & 0.84 & 0.00 & 2.43 \\
\hline $\begin{array}{l}\text { Sthenelais } \\
\text { limicola }\end{array}$ & Pred, Scav ${ }^{\mathrm{a}}$ & B & 3 & 0.10 & 0.71 & 2.28 \\
\hline $\begin{array}{l}\text { Ophelina } \\
\text { acuminata }\end{array}$ & SubDF $^{\mathrm{a}}$ & $\mathrm{B}$ & 3 & 0.20 & 0.76 & 2.27 \\
\hline Chaetozone sp. & $\mathrm{SDF}^{\mathrm{a}}$ & $\mathrm{SM}$ & 2 & 0.00 & 0.64 & 2.07 \\
\hline $\begin{array}{l}\text { Magelona } \\
\text { johnstoni }\end{array}$ & $\mathrm{SDF}^{\mathrm{a}}$ & SM & 2 & 0.20 & 0.66 & 2.03 \\
\hline Dosinia lupinus & $\mathrm{ASF}^{\mathrm{a}}, \mathrm{PSF}$ & $\mathrm{SM}$ & 2 & 0.54 & 0.00 & 1.94 \\
\hline $\begin{array}{l}\text { Poecilochaetus } \\
\text { serpens }\end{array}$ & $\begin{array}{l}\text { SDF, SubDF, PSF, ASF } \\
\text { (MarLIN 2006) }\end{array}$ & SM & 2 & 0.54 & 0.41 & 1.91 \\
\hline $\begin{array}{l}\text { Thracia } \\
\text { phaseolina }\end{array}$ & $\begin{array}{l}\text { PSF, ASF, SDF, SubDF } \\
\quad \text { (MarLIN 2006) }\end{array}$ & $\mathrm{UC} / \mathrm{DC}$ & 2 & 0.47 & 0.34 & 1.79 \\
\hline Aricidea $s p$ & $\mathrm{SDF}^{\mathrm{a}}, \mathrm{SubDF}$ & SM & 3 & 0.58 & 0.10 & 1.75 \\
\hline $\begin{array}{l}\text { Spiophanes } \\
\text { bombyx }\end{array}$ & $\begin{array}{l}\text { PSF, ASF, SDF, SubDF } \\
\text { (MarLIN 2006) }\end{array}$ & $\mathrm{UC} / \mathrm{DC}$ & 1 & 0.61 & 0.10 & 1.70 \\
\hline $\begin{array}{l}\text { Corystes } \\
\text { crassivelanus }\end{array}$ & Pred, Scav (MarLIN 2006) & $\mathrm{R}$ & 4 & 0.40 & 0.60 & 1.67 \\
\hline Venus casina & $\mathrm{ASF}^{\mathrm{a}}, \mathrm{PSF}$ & SM & 2 & 0.44 & 0.30 & 1.62 \\
\hline $\begin{array}{l}\text { Ophiuroid } \\
\text { juvenile }\end{array}$ & - & SM & 2 & 0.54 & 0.10 & 1.61 \\
\hline $\begin{array}{l}\text { Scalibregma } \\
\text { inflatum }\end{array}$ & $\begin{array}{l}\text { SDF, SubDF (MarLIN } \\
\text { 2006) }\end{array}$ & $\mathrm{B}$ & 4 & 0.14 & 0.50 & 1.58 \\
\hline Abra alba & $\begin{array}{l}\text { PSF, ASF, SDF, SubDF } \\
\quad \text { (MarLIN 2006) }\end{array}$ & SM & 2 & 0.00 & 0.56 & 1.57 \\
\hline Nephtys caeca & Pred, Scav (MarLIN 2006) & $\mathrm{B}$ & 3 & 0.44 & 0.00 & 1.53 \\
\hline Goniada sp. & Pred, Scav (MarLIN 2006) & $\mathrm{B}$ & 3 & 0.34 & 0.24 & 1.51 \\
\hline Ensis juvenile & ASF (MarLIN 2006) & SM & 2 & 0.34 & 0.20 & 1.22 \\
\hline
\end{tabular}


Table 3 continued

\begin{tabular}{|c|c|c|c|c|c|c|}
\hline Species & Feeding mode & $\begin{array}{l}\text { Sediment reworking } \\
\text { functional type } \\
\text { (Queiros et al. 2013) }\end{array}$ & $\begin{array}{l}\text { Mobility } \\
\text { (Queiros } \\
\text { et al. 2013) }\end{array}$ & $\begin{array}{l}\text { Low fishing } \\
\text { frequency }\end{array}$ & $\begin{array}{l}\text { High fishing } \\
\text { frequency }\end{array}$ & $\begin{array}{l}\text { Contr. } \\
\text { diss. }(\%)\end{array}$ \\
\hline Sthenelais sp. & Pred $^{\mathrm{a}}$, Scav & $\mathrm{B}$ & 3 & 0.00 & 0.38 & 1.20 \\
\hline Nephtys sp. & Pred, Scav (MarLIN 2006) & $\mathrm{B}$ & 3 & 0.10 & 0.34 & 1.15 \\
\hline Spio sp. & $\begin{array}{l}\text { SDF, SubDF (MarLIN } \\
\text { 2006) }\end{array}$ & $\mathrm{UC} / \mathrm{DC}$ & 2 & 0.30 & 0.20 & 1.14 \\
\hline Terebellidae & - & $\mathrm{UC} / \mathrm{DC}$ & 1 & 0.20 & 0.24 & 1.09 \\
\hline Syllidae & - & $\mathrm{B}$ & 3 & 0.00 & 0.30 & 1.05 \\
\hline Abra prismatica & $\begin{array}{l}\text { PSF, ASF, SDF, SubDF } \\
\quad \text { (MarLIN 2006) }\end{array}$ & $\mathrm{SM}$ & 2 & 0.24 & 0.00 & 0.79 \\
\hline $\begin{array}{l}\text { Gattyana } \\
\text { cirrhosa }\end{array}$ & Pred, Scav (MarLIN 2006) & $\mathrm{B}$ & 3 & 0.10 & 0.20 & 0.76 \\
\hline Nematoda & - & SM & 2 & 0.00 & 0.24 & 0.75 \\
\hline $\begin{array}{l}\text { Scolelepis } \\
\text { squamata }\end{array}$ & $\mathrm{SDF}^{\mathrm{a}}$ & UC/DC & 2 & 0.24 & 0.00 & 0.70 \\
\hline $\begin{array}{r}\text { Scoloplos } \\
\text { armiger }\end{array}$ & SubDF $^{\mathrm{a}}$ & B & 3 & 0.24 & 0.00 & 0.70 \\
\hline Sabellidae & - & SM & 1 & 0.10 & 0.20 & 0.64 \\
\hline $\begin{array}{l}\text { Bathyporeia } \\
\text { gracilis }\end{array}$ & $\mathrm{SDF}^{\mathrm{a}}, \mathrm{SubDF}$ & $\mathrm{SM}$ & 3 & 0.20 & 0.00 & 0.57 \\
\hline Orbinia sp. & $\operatorname{SubDF}^{\mathrm{a}}$ & $\mathrm{B}$ & 3 & 0.10 & 0.10 & 0.57 \\
\hline Pagurus sp. & $\begin{array}{l}\text { SDF, Pred, ASF (MarLIN } \\
\text { 2006) }\end{array}$ & $\mathrm{E}$ & 4 & 0.00 & 0.20 & 0.53 \\
\hline Cerebratulus sp. & Pred $^{\mathrm{a}}$, Scav & $\mathrm{B}$ & 3 & 0.20 & 0.00 & 0.52 \\
\hline \multicolumn{7}{|c|}{ b. Groups tested: Taxon biomass between low and high fishing activity in sandy sediment } \\
\hline $\begin{array}{l}\text { Echinocardium } \\
\text { cordatum }\end{array}$ & $\begin{array}{l}\text { SDF, SubDF (MarLIN } \\
\text { 2006) }\end{array}$ & $\mathrm{B}$ & 3 & 0.28 & 1.06 & 19.76 \\
\hline $\begin{array}{l}\text { Corystes } \\
\text { crassivelanus }\end{array}$ & Pred, Scav (MarLIN 2006) & $\mathrm{R}$ & 4 & 0.30 & 0.29 & 11.17 \\
\hline $\begin{array}{l}\text { Thracia } \\
\text { phaseolina }\end{array}$ & $\begin{array}{l}\text { PSF, ASF, SDF, SubDF } \\
\quad \text { (MarLIN 2006) }\end{array}$ & $\mathrm{UC} / \mathrm{DC}$ & 2 & 0.05 & 0.25 & 6.19 \\
\hline Lagis koreni & SubDF(MarLIN 2006) & $\mathrm{UC} / \mathrm{DC}$ & 1 & 0.23 & 0.12 & 6.06 \\
\hline $\begin{array}{l}\text { Acanthocardia } \\
\text { echinata }\end{array}$ & PSF, ASF (MarLIN 2006) & SM & 2 & 0.00 & 0.24 & 4.94 \\
\hline $\begin{array}{r}\text { Chamelea } \\
\text { striatula }\end{array}$ & PSF, ASF (MarLIN 2006) & SM & 2 & 0.00 & 0.17 & 4.41 \\
\hline Nephtys incisa & $\begin{array}{l}\text { SDF, SubDF (MarLIN } \\
\text { 2006) }\end{array}$ & $\mathrm{B}$ & 3 & 0.09 & 0.03 & 3.06 \\
\hline $\begin{array}{l}\text { Glycera } \\
\quad \text { oxycephala }\end{array}$ & Pred, Scav (MarLIN 2006) & $\mathrm{B}$ & 3 & 0.11 & 0.01 & 2.94 \\
\hline Phoronis sp. & PSF, ASF (MarLIN 2006) & SM & 1 & 0.01 & 0.1 & 2.56 \\
\hline $\begin{array}{l}\text { Sigalion } \\
\text { mathilde }\end{array}$ & Pred $^{\mathrm{a}}, \mathrm{Scav}$ & $\mathrm{B}$ & 3 & 0.00 & 0.06 & 2.13 \\
\hline Lumbrineris sp. & Pred, Scav (MarLIN 2006) & B & 3 & 0.00 & 0.07 & 1.96 \\
\hline $\begin{array}{l}\text { Ophelina } \\
\text { acuminata }\end{array}$ & SubDF $^{\mathrm{a}}$ & $\mathrm{B}$ & 3 & 0.01 & 0.06 & 1.92 \\
\hline
\end{tabular}


Table 3 continued

\begin{tabular}{|c|c|c|c|c|c|c|}
\hline Species & Feeding mode & $\begin{array}{l}\text { Sediment reworking } \\
\text { functional type } \\
\text { (Queiros et al. 2013) }\end{array}$ & $\begin{array}{l}\text { Mobility } \\
\text { (Queiros } \\
\text { et al. 2013) }\end{array}$ & $\begin{array}{l}\text { Low fishing } \\
\text { frequency }\end{array}$ & $\begin{array}{l}\text { High fishing } \\
\text { frequency }\end{array}$ & $\begin{array}{l}\text { Contr. } \\
\text { diss. }(\%)\end{array}$ \\
\hline $\begin{array}{l}\text { Owenia } \\
\text { fusiformis }\end{array}$ & $\begin{array}{l}\text { PSF, ASF, SDF, SubDF } \\
\text { (MarLIN 2006) }\end{array}$ & SM & 1 & 0.01 & 0.07 & 1.91 \\
\hline $\begin{array}{l}\text { Sthenelais } \\
\quad \text { limicola }\end{array}$ & Pred $^{\mathrm{a}}, \mathrm{Scav}$ & $\mathrm{B}$ & 3 & 0.01 & 0.05 & 1.88 \\
\hline Venus casina & $\mathrm{ASF}^{\mathrm{a}}, \mathrm{PSF}$ & SM & 2 & 0.03 & 0.07 & 1.85 \\
\hline $\begin{array}{l}\text { Scolelepis } \\
\text { squamata }\end{array}$ & $\mathrm{SDF}^{\mathrm{a}}$ & $\mathrm{UC} / \mathrm{DC}$ & 2 & 0.06 & 0.00 & 1.38 \\
\hline Pagurus sp. & $\begin{array}{l}\text { SDF, Pred, ASF (MarLIN } \\
\text { 2006) }\end{array}$ & $\mathrm{E}$ & 4 & 0.00 & 0.04 & 1.36 \\
\hline Abra alba & $\begin{array}{l}\text { PSF, ASF, SDF, SubDF } \\
\text { (MarLIN 2006) }\end{array}$ & SM & 2 & 0.00 & 0.07 & 1.26 \\
\hline Abra prismatica & $\begin{array}{l}\text { PSF, ASF, SDF, SubDF } \\
\text { (MarLIN 2006) }\end{array}$ & SM & 2 & 0.04 & 0.00 & 1.26 \\
\hline $\begin{array}{l}\text { Asteroid } \\
\text { juvenile }\end{array}$ & - & $\mathrm{E}$ & 3 & 0.04 & 0.00 & 1.22 \\
\hline Cerianthus sp. & PSF, Pred (MarLIN 2006) & SM & 1 & 0.00 & 0.05 & 1.18 \\
\hline Nucula hanleyi & $\begin{array}{l}\text { SubDF, Det (MarLIN } \\
\text { 2006) }\end{array}$ & SM & 3 & 0.00 & 0.05 & 1.01 \\
\hline Dosinia lupinus & $\mathrm{ASF}^{\mathrm{a}}, \mathrm{PSF}$ & SM & 2 & 0.03 & 0.00 & 0.95 \\
\hline Glycera alba & Pred, Scav (MarLIN 2006) & $\mathrm{B}$ & 3 & 0.02 & 0.01 & 0.88 \\
\hline Travisia forbesi & $\begin{array}{l}\text { SDF, SubDF (MarLIN } \\
\text { 2006) }\end{array}$ & B & 3 & 0.03 & 0.00 & 0.87 \\
\hline Ensis juvenile & ASF (MarLIN 2006) & SM & 2 & 0.00 & 0.03 & 0.82 \\
\hline $\begin{array}{l}\text { Scalibregma } \\
\text { inflatum }\end{array}$ & $\begin{array}{l}\text { SDF, SubDF (MarLIN } \\
\text { 2006) }\end{array}$ & $\mathrm{B}$ & 4 & 0.01 & 0.02 & 0.80 \\
\hline $\begin{array}{l}\text { Gattyana } \\
\text { cirrhosa }\end{array}$ & Pred, Scav (MarLIN 2006) & B & 3 & 0.02 & 0.02 & 0.77 \\
\hline Sthenelais sp. & Pred $^{\mathrm{a}}$, Scav & $\mathrm{B}$ & 3 & 0.00 & 0.05 & 0.77 \\
\hline
\end{tabular}

Information on species feeding mode/s (SDF for surface deposit feeder; SubDF for subsurface deposit feeder; ASF for active suspension feeder; PSF for passive suspension feeder; Pred for predator; Scav for scavenger; Det for detritivore; feeding mode was not allocated to taxon level higher than genus and are denoted by “-”), sediment reworking functional type (E for epifauna; SM for surficial modifiers; UC/DC for upward and downward conveyors; B for biodiffusors; and R for regenerators) and mobility ( 1 for organisms that live in fixed tubes; 2 indicates limited movement; 3 indicates slow, free movement through the sediment matrix; 4 indicates free movement via burrow system) are provided

${ }^{a}$ Biological traits database developed under the BENTHIS (Benthic Ecosystem Fisheries Impact Studies) project. [16/07/2016]. http://www.benthis.eu/en/benthis/Results.htm

suspension to deposit feeders did not differ between any of our treatments (Model 19, Table 4). Sediment reworking group density (Model 20, Table 4), however, reflected the independent effects of fishing frequency (Fig. 5e), organic matter enrichment (Fig. 5f) and sediment reworking group identity (Fig. 5g), whilst sediment reworking group biomass was influenced solely by sediment reworking group identity (Model 21, Table 4 with a greater biomass attributed to biodiffusors (e.g. Goneplax rhomboides,
Nepthys sp.) (Fig. 5h). Nevertheless, community composition did not differ between sites of low and high fishing frequency (PERMANOVA, density: Pseudo-F $=1.30, \quad \mathrm{p}=0.25 ; \quad$ biomass, $\quad$ Pseudo$\mathrm{F}=1.37, \mathrm{p}=0.22$, ESM 5) or between enriched and non-enriched treatments (density: Pseudo$\mathrm{F}=0.82, \quad \mathrm{p}=0.55 ; \quad$ biomass: $\quad$ Pseudo- $\mathrm{F}=0.74$, $\mathrm{p}=0.63$ ) (Fig. 6).

T-RFLP profiling for archaeal and bacterial $16 \mathrm{~S}$ rRNA genes did not reveal any differences in total 
(a)

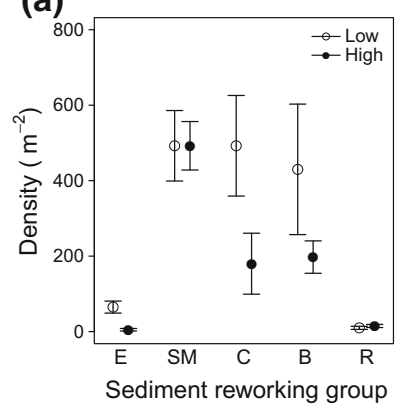

(b)

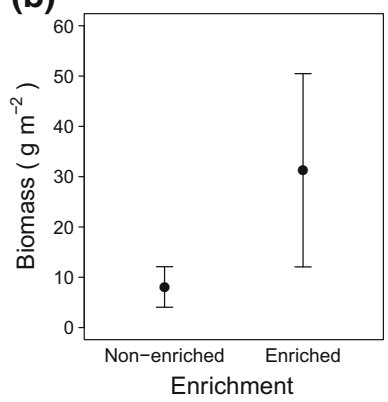

(c)

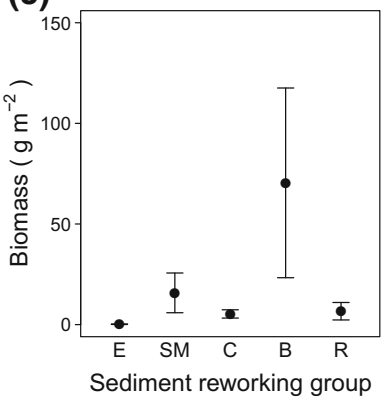

Fig. 2 The a interactive effects of sediment reworking group identity and the frequency of fishing on sediment reworking group density, and $\mathbf{b}, \mathbf{c}$ the independent effects of organic matter enrichment and sediment reworking group identity on sediment reworking group biomass in sandy sediments (mean \pm SE). In a contrasting levels of bottom fishing frequency (open symbol low, closed symbol high) are presented. In a and c sediment reworking groups include epifauna $(E)$, surficial modifiers $(S M)$, conveyors $(C)$, biodiffusors $(B)$ and regenerators $(R)$
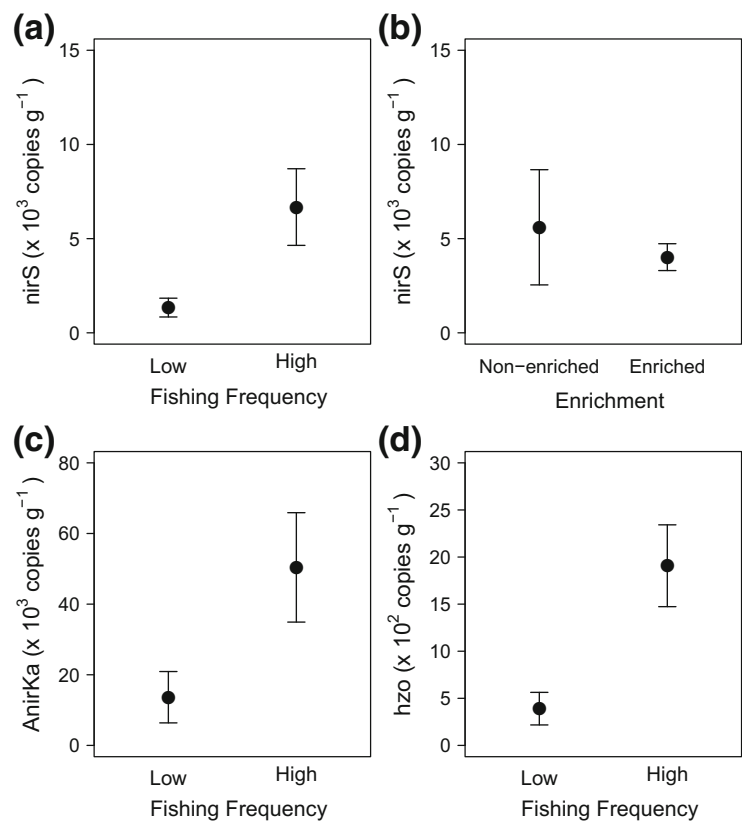

Fig. 3 The independent effects of a fishing frequency and b organic matter enrichment on abundance of the metabolically active bacterial denitrifier (nirS) and the independent effect of fishing frequency on $\mathbf{c}$ archaeal (AnirKa) denitrifiers and d anammox $(h z o)$ hydrazine oxidoreductase transcripts in sandy sediments. Values plotted are mean $\pm \mathrm{SE}$

microbial community structure that related to either fishing frequency (PERMANOVA, Archaea: Pseudo$\mathrm{F}=1.07, \quad \mathrm{p}=0.37 ; \quad$ Bacteria: $\quad$ Pseudo-F $=1.47$, $\mathrm{p}=0.15$ ), or organic matter enrichment (Archaea: Pseudo-F $=0.23, \quad \mathrm{p}=0.95 ; \quad$ Bacteria: Pseudo$\mathrm{F}=1.29, \mathrm{p}=0.24)(\mathrm{ESM} 4$ Fig. S3). Indeed, we (a)

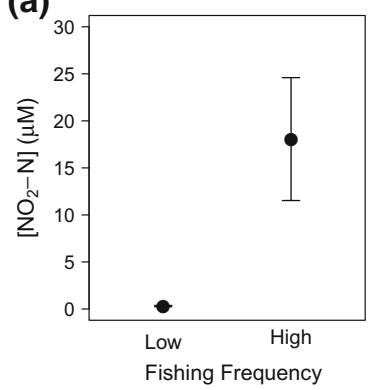

(b)

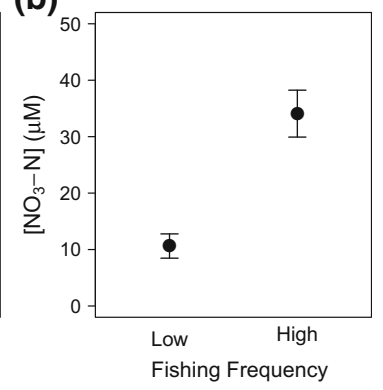

Fig. 4 The independent effect of fishing frequency on $\mathbf{a}\left[\mathrm{NO}_{2}-\right.$ $\mathrm{N}]$ and $\mathbf{b}\left[\mathrm{NO}_{3}-\mathrm{N}\right]$ in sandy sediments. Values plotted are mean $\pm \mathrm{SE}$

were unable to find any evidence supporting the view that bacterial denitrifers (nirS transcripts, range: 903-6330 copies $\mathrm{g}^{-1}$ sediment), anammox (hzo transcripts, range: $3160-165,000$ copies $\mathrm{g}^{-1}$ sediment) or bacterial (AOB amoA transcripts, range: 1270-251,000 copies $\mathrm{g}^{-1}$ sediment) or archaeal ammonia oxidisers (AOA amoA transcripts, range: 2700-83,900 copies $\mathrm{g}^{-1}$ sediment) respond to differences in fishing frequency or organic matter enrichment (Models 22, 24-26, Table 4). In contrast, however, archaeal (AnirKa) denitrifiers did respond (Model 23, Table 4) positively to the effects of increasing fishing frequency (Fig. 7a) and negatively to increasing organic matter enrichment (Fig. 7b), although these effects were independent of one another. We also found evidence that the mean ratio of bacterial to archaeal ammonia oxidisers (AOB: AOA amoA) increased with organic matter enrichment (Model 27, Table 4, Fig. 7c). 
Table 4 Linear regression models to examine the effects of fishing frequency and enrichment (full factorial, $\mathrm{F} \times \mathrm{E}$ ) in sandy mud $(s M)$, for macro-invertebrate community (Models 16-19: invertebrate density, biomass and species richness, the ratio of suspension to deposit feeders), sediment reworking groups $\left(\mathrm{R}_{\mathrm{i}}\right.$, reworking group density and biomass, Models
20-21), microbial community (Models 22-27: abundance of bacterial and archaeal denitrifiers (nirS, AnirKa), anammox (hzo), archaeal and bacterial nitrifiers (AOA amoA, AOB $a m o A)$ and ratio of bacterial and archaeal $a m o A$ transcripts) and associated levels of dissolved inorganic nitrogen (Models 28-30: $\left.\left[\mathrm{NO}_{2}-\mathrm{N}\right],\left[\mathrm{NO}_{3}-\mathrm{N}\right],\left[\mathrm{NH}_{4}-\mathrm{N}\right]\right)$

Sediment type: sandy Mud (sM)

\begin{tabular}{|c|c|c|c|c|c|c|c|}
\hline \multicolumn{8}{|c|}{ Macro-invertebrate community (Initial linear model: response variable $\sim \mathrm{F} \times \mathrm{E}$ ) } \\
\hline $\begin{array}{l}\text { Model } \\
\text { ID }\end{array}$ & Model & Response variable & $\begin{array}{l}\text { Fishing frequency } \\
\text { (F) }\end{array}$ & Enrichment (E) & $\begin{array}{l}\text { Interaction } \\
(\mathrm{F}: \mathrm{E})\end{array}$ & Intercept only & $\begin{array}{l}\text { Variance- } \\
\text { covariate }\end{array}$ \\
\hline 16 & GLS & $\begin{array}{l}\text { Macro-invertebrate } \\
\text { density }\end{array}$ & $\begin{array}{c}\mathrm{L}=5.27 \\
\mathrm{df}=1 \\
\mathrm{p}=0.02\end{array}$ & $\begin{array}{l}\mathrm{L}=4.31, \mathrm{df}=1 \\
\mathrm{p}=0.04\end{array}$ & & & $\mathrm{~F}$ \\
\hline 17 & GLS & Species richness & $\begin{array}{c}\mathrm{L}=3.83 \\
\mathrm{df}=1 \\
\mathrm{p}=0.05\end{array}$ & $\begin{array}{l}\mathrm{L}=7.75, \mathrm{df}=1 \\
\mathrm{p}=0.005\end{array}$ & & & $\mathrm{~F}$ \\
\hline 18 & GLS & $\begin{array}{l}\text { Macro-invertebrate } \\
\text { biomass }\end{array}$ & & & & $\begin{array}{l}\mathrm{L}=1.29, \mathrm{df}=1 \\
\mathrm{p}=0.26\end{array}$ & $\mathrm{~F} \times \mathrm{E}$ \\
\hline 19 & LM & $\begin{array}{l}\text { suspension: deposit } \\
\text { feeders ratio }\end{array}$ & & & & $\begin{array}{c}\mathrm{F}=12.33 \\
\mathrm{df}=16 \\
\mathrm{p}=0.77\end{array}$ & - \\
\hline
\end{tabular}

Sediment reworking groups (Initial linear model: Response variable $\sim \mathrm{F} \times \mathrm{E} \times \mathrm{Ri}$ )

\begin{tabular}{|c|c|c|c|c|c|c|c|c|}
\hline $\begin{array}{l}\text { Model } \\
\text { ID }\end{array}$ & Model & $\begin{array}{l}\text { Response } \\
\text { variable }\end{array}$ & $\begin{array}{l}\text { Fishing frequency } \\
\text { (F) }\end{array}$ & Enrichment (E) & $\begin{array}{l}\text { Reworking mode } \\
\text { (Ri) }\end{array}$ & $\mathrm{F}: \mathrm{E} \quad \mathrm{F}: \mathrm{Ri}$ & $\begin{array}{l}\text { Intercept } \\
\text { only }\end{array}$ & $\begin{array}{l}\text { Variance- } \\
\text { covariate }\end{array}$ \\
\hline 20 & GLS & Ri density & $\begin{array}{c}\mathrm{L}=8.51, \mathrm{df}=1 \\
\mathrm{p}=0.004\end{array}$ & $\begin{array}{c}\mathrm{L}=5.59 \\
\mathrm{df}=1 \\
\mathrm{p}=0.02\end{array}$ & $\begin{array}{c}\mathrm{L}=54.17, \mathrm{df}=1 \\
\mathrm{p}<0.0001\end{array}$ & & & $\mathrm{~F} \times \mathrm{E}$ \\
\hline 21 & GLS & Ri biomass & & & $\begin{array}{c}\mathrm{L}=8.23, \mathrm{df}=1 \\
\mathrm{p}=0.02\end{array}$ & & & $\mathrm{~F} \times \mathrm{Ri}$ \\
\hline
\end{tabular}

Abundance of active $\mathrm{N}$-cycling associated microbes (Initial linear model: response variable $\sim \mathrm{F} \times \mathrm{E}$ )

\begin{tabular}{|c|c|c|c|c|c|c|c|}
\hline $\begin{array}{l}\text { Model } \\
\text { ID }\end{array}$ & Model & $\begin{array}{l}\text { Response } \\
\text { variable }\end{array}$ & $\begin{array}{l}\text { Fishing frequency } \\
\text { (F) }\end{array}$ & Enrichment (E) & $\begin{array}{l}\text { Interaction } \\
(\mathrm{F}: \mathrm{E})\end{array}$ & Intercept only & $\begin{array}{l}\text { Variance- } \\
\text { covariate }\end{array}$ \\
\hline 22 & LM & $\operatorname{nir} S$ & & & & $\begin{array}{l}\mathrm{F}=0.005, \mathrm{df}=17 \\
\mathrm{p}=0.94\end{array}$ & - \\
\hline 23 & LM & AnirKa & $\begin{array}{l}\mathrm{F}=3.86, \mathrm{df}=1 \\
\mathrm{p}=0.07\end{array}$ & $\begin{array}{l}\mathrm{F}=3.97, \mathrm{df}=1 \\
\mathrm{p}=0.06\end{array}$ & & & - \\
\hline 24 & LM & hzo & & & & $\begin{array}{l}\mathrm{F}=0.33, \mathrm{df}=17 \\
\mathrm{p}=0.57\end{array}$ & - \\
\hline 25 & LM & AOA $a m o A$ & & & & $\begin{array}{l}\mathrm{F}=0.46 \mathrm{df}=17 \\
\mathrm{p}=0.51\end{array}$ & - \\
\hline 26 & LM & AOB $a m o A$ & & & & $\begin{array}{l}F=0.17, d f=17 \\
p=0.68\end{array}$ & - \\
\hline 27 & LM & $\begin{array}{l}\text { AOB: AOA } \\
\text { amoA ratio }\end{array}$ & & $\begin{array}{c}F=13.33, d f=1 \\
p=0.002\end{array}$ & & & - \\
\hline
\end{tabular}

Water nutrient concentration (Initial linear model: response variable $\sim \mathrm{F} \times \mathrm{E}$ )

\begin{tabular}{llllllll}
\hline $\begin{array}{l}\text { Model } \\
\text { ID }\end{array}$ & Model & $\begin{array}{l}\text { Response } \\
\text { variable }\end{array}$ & $\begin{array}{l}\text { Fishing frequency } \\
(\mathrm{F})\end{array}$ & $\begin{array}{l}\text { Enrichment } \\
(\mathrm{E})\end{array}$ & $\begin{array}{l}\text { Interaction } \\
(\mathrm{F}: \mathrm{E})\end{array}$ & $\begin{array}{l}\text { Intercept only } \\
\text { Variance- } \\
\text { covariate }\end{array}$ & \begin{tabular}{l}
$\mathrm{F} \times \mathrm{E}$ \\
\hline
\end{tabular} \\
\hline
\end{tabular}


Table 4 continued

Water nutrient concentration (Initial linear model: response variable $\sim \mathrm{F} \times \mathrm{E}$ )

\begin{tabular}{|c|c|c|c|c|c|c|c|}
\hline $\begin{array}{l}\text { Model } \\
\text { ID }\end{array}$ & Model & $\begin{array}{l}\text { Response } \\
\text { variable }\end{array}$ & $\begin{array}{l}\text { Fishing frequency } \\
\text { (F) }\end{array}$ & $\begin{array}{l}\text { Enrichment } \\
\text { (E) }\end{array}$ & $\begin{array}{l}\text { Interaction } \\
(\mathrm{F}: \mathrm{E})\end{array}$ & Intercept only & $\begin{array}{l}\text { Variance- } \\
\text { covariate }\end{array}$ \\
\hline & & & & & & $\begin{array}{l}\mathrm{L}=1.37, \mathrm{df}=1 \\
\mathrm{p}=0.24\end{array}$ & \\
\hline 29 & LM & {$\left[\mathrm{NO}_{3}-\mathrm{N}\right]$} & & & & $\begin{array}{l}\mathrm{F}=0.49, \mathrm{df}=19 \\
\mathrm{p} 0.49\end{array}$ & - \\
\hline 30 & GLS & {$\left[\mathrm{NH}_{4}-\mathrm{N}\right]$} & & & & $\begin{array}{c}\mathrm{L}=1.73, \mathrm{df}=1 \\
\mathrm{p}=0.19\end{array}$ & $F \times E$ \\
\hline
\end{tabular}

The test statistic (L-ratio or F value), degrees of freedom (df) and probability value ( $\mathrm{p}$ ) are listed for marginal ( $\mathrm{p}<0.075)$ or significant $(\mathrm{p}<0.05)$ terms. Where all independent variables were found insignificant, we present the intercept only model. The class of variance-covariate used to specify different variances for each level of stratification within-group are also provided
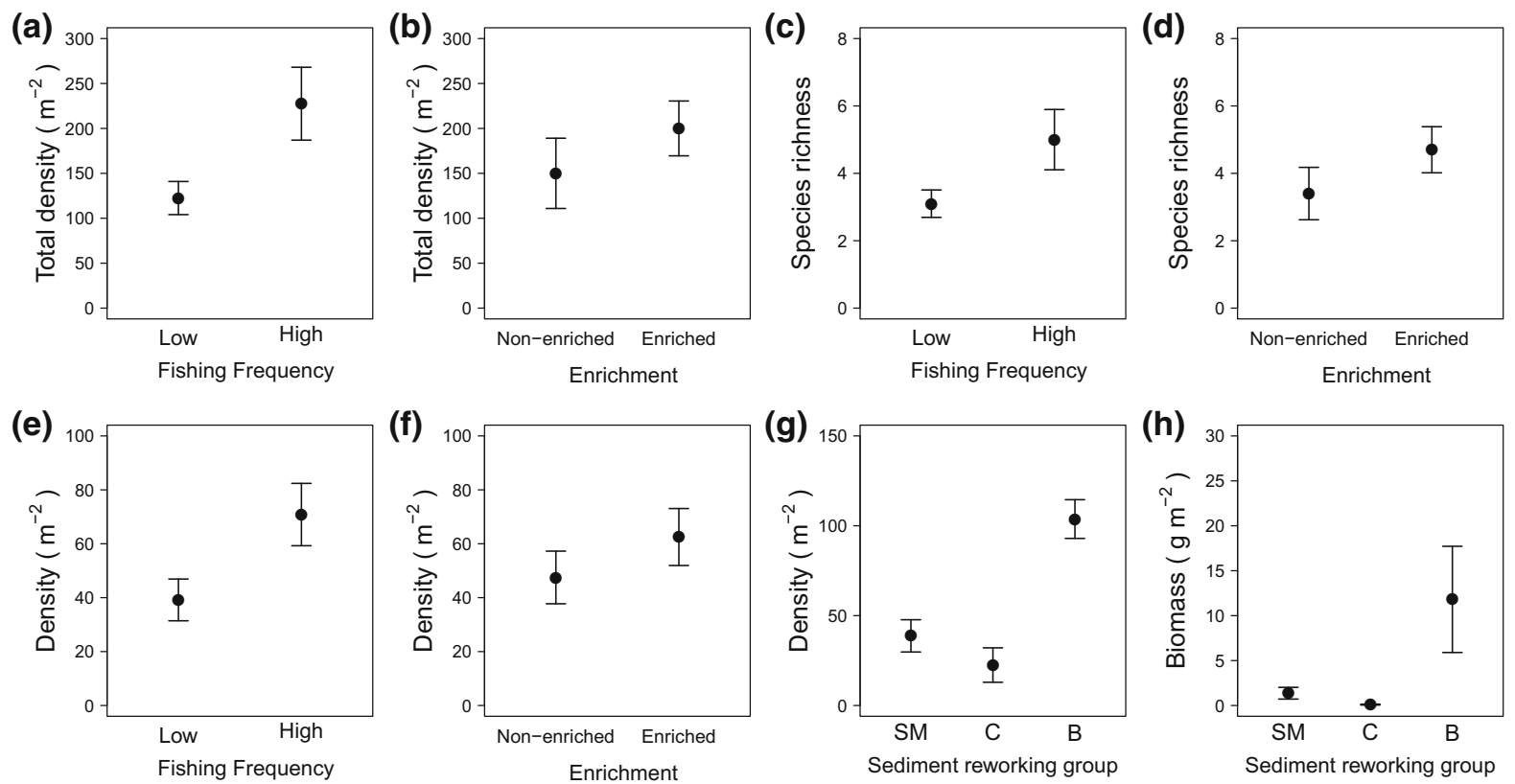

Fig. 5 The independent effects of fishing frequency and organic matter enrichment on $\mathbf{a}, \mathbf{b}$ total macrofaunal density $\mathbf{c}$, d species richness and $\mathbf{e}, \mathbf{f}$ sediment reworking group density. Sediment reworking group density $\mathbf{g}$ and biomass $\mathbf{h}$ were

Despite changes in the microbial and macrofaunal attributes of our sandy mud communities, $\left[\mathrm{NH}_{4}-\mathrm{N}\right]$, $\left[\mathrm{NO}_{2}-\mathrm{N}\right]$ and $\left[\mathrm{NO}_{3}-\mathrm{N}\right]$ were not affected by fishing frequency or organic matter enrichment (Models 28-30, Table 4).

\section{Discussion}

Our findings suggest that nitrogen transformation in shelf sea sediments is dependent on whether specific

dependent on sediment reworking group identity ( $S M$ surficial modifiers, $C$ conveyors, $B$ biodiffusors). There were no species for sediment reworking groups $\mathrm{E}$ (epifauna) and R (regenerators) in sandy mud. Values plotted are mean $\pm \mathrm{SE}$

microbial transcripts are influenced by differences in the composition of the bioturbating macrofauna, environmental context (here, nutrient enrichment and sediment type), and recent history of anthropogenic disturbance (here, frequency of bottom fishing), although these effects are not necessarily interactive and their relative importance is context dependent (Wohlgemuth et al. 2017). We find that the modification of invertebrate community structure following bottom fishing is particularly important for the mediation of biogeochemical processes and is not 


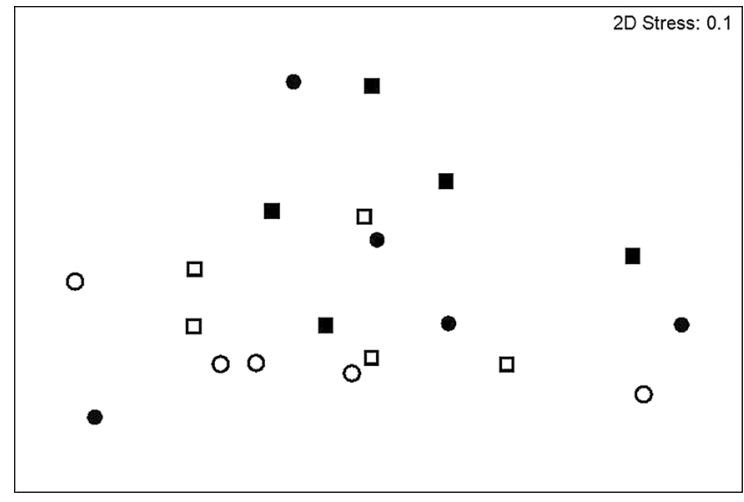

Fig. 6 Non-metric multidimensional scaling (nMDS) ordination of square-root transformed Bray-Curtis resemblance matrix of macro-invertebrate density for communities in sandy mud that experienced contrasting levels of bottom fishing frequency (open symbol low, closed symbol high) and of organic enrichment (circle non-enriched, square enriched). MDS dimensionality representation stress value $=0.1$

necessarily offset by the effects of organic matter enrichment on microbial composition and activity. These effects were observed in sand but not in sandy mud (where the range of fishing frequency from bottom-towed fishing gear was higher than that in the sandy area). In sand, we found that sediment characterized by higher ratios of suspension to deposit feeders and a lower density but higher biomass of bioturbating fauna, was associated with increased activity of denitrifying archaea and bacteria (AnirKa, nirS) and anammox (hzo) and higher levels of bottom water $\left[\mathrm{NO}_{2}-\mathrm{N}\right]$ and $\left[\mathrm{NO}_{3}-\mathrm{N}\right]$. The higher biomass of bioturbating species, in particular Echinocardium cordatum, Acanthocardia echinata and Chamelea striatula and the higher density of bioirrigating tube- building species such as Phoronis sp. and Owenia fusiformis, offers an explanation for the enhanced denitrifier activity. E. cordatum is known to displace large volumes of sediment $\left(20,000 \mathrm{~cm}^{3} \mathrm{~m}^{-2}\right.$ day $^{-1}$ by 40 individuals $\mathrm{m}^{-2}$, Lohrer et al. 2005) and although the shallow-burying bivalves $A$. echinata and $C$. striatula and the tube-building polychaetes do not build extensive burrow systems deep within the sediment, their active mixing of the uppermost sediment layers and their dominating biomass, means that their bioturbation activities are likely to have stimulated microbial denitrification and anammox, possibly by increasing the flux of $\left[\mathrm{NO}_{2}-\mathrm{N}\right]$ and $\left[\mathrm{NO}_{3}-\right.$ $\mathrm{N}]$ across the water-sediment interface, which constitutes the substrate for nitrite reductase and anammox (Howe et al. 2004; Dang et al. 2010). Measured sediment particle reworking rates using fluorescent sediment profile imaging techniques at the same study sites confirm more intense particle reworking activity in communities that have previously experienced a higher frequency of bottom fishing, substantially extending the maximum depth of sediment reworking (low frequency fishing, $1.99 \pm 0.19 \mathrm{~cm}$; high frequency fishing, $4.64 \pm 0.5 \mathrm{~cm}$ ) and increasing the volume of sediment available for nitrification (Hale et al. 2017). It is interesting to note that, although some bioturbation groups-such as biodiffusors and upwards/downwards conveyors-were, on average, twice as abundant at sites with a history of low frequency of fishing, the biomass of biodiffusors and surficial modifiers was substantively higher (24 times and 60 times higher, respectively) at sites with a history of high frequency of fishing. It appears that biomass had an overriding effect over density; larger (a)

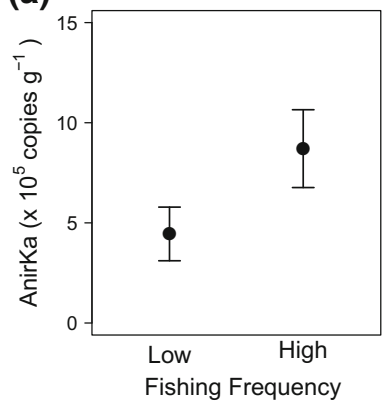

(b)

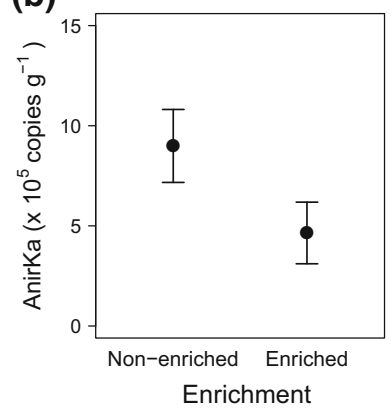

(c)

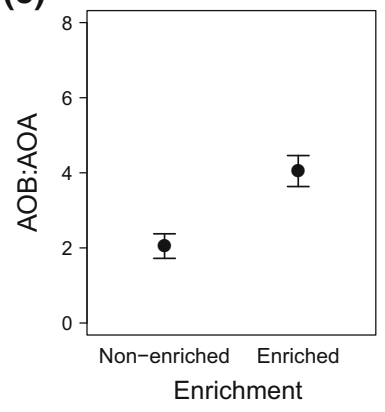

Fig. 7 The independent effects of a fishing frequency and $\mathbf{b}$ organic matter enrichment on archaeal (AnirKa) denitrifiers, and of c organic matter enrichment on the ratio of bacterial to archaeal ammonia oxidisers (AOB:AOA amoA). Values plotted are mean $\pm \mathrm{SE}$ 
individuals with a greater per capita effect on sediment mixing have a disproportionate effect on microbial activity and composition and, in turn, nutrient concentrations (Osinga et al. 1995; Bird et al. 1999). The increased abundance of active suspension feeders (relative to deposit feeders) is also likely to have stimulated microbial denitrification and anammox, through an increase in the provision of $\left[\mathrm{NO}_{2}-\mathrm{N}\right]$ and $\left[\mathrm{NO}_{3}-\mathrm{N}\right]$ as water is actively moved into the sediment during feeding (Howe et al. 2004; Dang et al. 2010). Although we may conclude that macrofaunal bioturbation and bioirrigation activities had a stimulatory effect on microbial denitrification, it remains unclear why we did not detect any change in archaeal or bacterial nitrifier (amoA gene) abundance in either sand or sandy mud sediments.

Given the findings elsewhere that report higher mortality of suspension feeders at locations that are subject to fishing activity (e.g. Tillin et al. 2006; van Denderen et al. 2015), it is surprising that we found a higher ratio of suspension to deposit feeders in sand communities that experienced a higher frequency of chronic fishing. However, a clear trend that emerges from previous studies is that the degree of natural disturbance in which a community develops determines the degree to which it is affected by bottom fishing (Kaiser and Spencer 1996; Hiddink et al. 2006; Sciberras et al. 2013). The macro-invertebrate communities at our sandy study sites are adapted to living in physically dynamic areas that are characterized by relatively high near-bed current flows (Hiddink et al. 2009) and infrequent fishing activity (1.63 times year ${ }^{-1}$ ), so community recruitment and growth is unlikely to be significantly affected by fishing. In contrast, the macroinvertebrate communities of our sandy mud sites show substantive compositional changes that relate to a fishing frequency of 3.8 times year $^{-1}$, such that further increases in fishing activity (8.4 times year $^{-1}$ ) have proportionally less effect on microbial and/or macrofaunal community composition and structure. We recognize that our study would benefit from additional locations where bottom fishing is absent, but such areas were not comparable as they were characterized by very different habitat conditions (sediment composition, tide and wave stress). In agreement with Braeckman et al. (2014), however, we find that that benthic functional diversity (expressed as community bioturbation potential, $\mathrm{BP}_{\mathrm{C}}$ ) had a strong influence on biogeochemical cycling (sediment community oxygen consumption, denitrification rates, alkalinity and $\mathrm{NH}_{4}$ fluxes) in sandy sediments with high $\mathrm{BP}_{\mathrm{C}}$ but not in muddy sediments, where the $\mathrm{BP}_{\mathrm{C}}$ was found to be significantly lower than in sand.

We hypothesized that the addition of organic matter would increase microbial activity (measured here as the gene transcript abundance). Thus, the correlation between enrichment and macrofaunal density and species richness in sandy mud and the relative biomass of different functional groups in sand was unexpected (given the short time scale of the experiment) and most likely the result of stochastic variation in the abundance of infauna and unrelated to the enrichment treatment. However, in sandy sediments, organic matter enrichment correlated with a reduction in the variation and mean activity of bacterial denitrifiers (nirS), and in sandy mud sediments with a reduction in mean activity of archaeal denitrifiers (AnirKa), and a change in ammonia oxidiser community structure, altering the ratio of ammonia oxidising bacteria to ammonia oxidising archaea (as in Gilbertson et al. 2012). An effect, however, was not found for all microbes measured, for example for the nitrifiers (AOB amoA, AOA amoA) and anammox (hzo) in either sand or sandy mud. A number of studies have reported increases in bacterial biomass and activity upon addition of organic material within days or even hours (e.g. Luna et al. 2002; Gihring et al. 2009). However, others have reported a delayed microbial response ( $\sim 1-2$ weeks) (Tait et al. 2015) as instead of feeding directly on sinking phytodetrital material, benthic microbes may consume the organic matter released via the grazing activity of deposit and suspension feeders, thus explaining the lack of response for some microbes in our study.

The lesser importance of organic matter enrichment relative to fishing frequency related changes in macrofaunal composition documented here, may be emphasising habitat-specific differences in organic matter incorporation rate and/or differences in the response time of different components of the benthic community. Our study highlights the importance of understanding the response of multiple ecosystem components over the longer term if we are to provide ecosystem-relevant evidence to underpin decisions that aim to secure the protection of natural capital (Pittman and Armitage, 2016), and ensure the sustainable management of coastal and shelf sea ecosystem services (Voss et al. 2013). 
Acknowledgements Supported by Work Package 2 of the Shelf Sea Biogeochemistry Programme (SSB, WP2, NE/ K001906/1 and NE/K001639/1, 2011-2017), jointly funded by the Natural Environment Research Council (NERC) and the Department for Environment, Food and Rural Affairs (Defra). We also acknowledge the use of data obtained under EU FP7 BENTHIS (Benthic Ecosystem Fisheries Impact Studies, project 312088). The views expressed are those of the authors and do not necessarily represent those of NERC or Defra. We thank the crew of RV Prince Madog, Ashleigh Currie, Leigh Howarth, Steve Balestrini, and Marine Cendrier for technical assistance. All data are available from the British Oceanographic Data Centre, https://www.bodc.ac.uk/data/ published_data_library/catalogue/10.5285/46ecc183-c08d2211-e053-6c86abc0d02c/ (doi:10.5285/46ecc183-c08d-2211e053-6c86abc0d02c).

Open Access This article is distributed under the terms of the Creative Commons Attribution 4.0 International License (http:// creativecommons.org/licenses/by/4.0/), which permits unrestricted use, distribution, and reproduction in any medium, provided you give appropriate credit to the original author(s) and the source, provide a link to the Creative Commons license, and indicate if changes were made.

\section{References}

Allen JI, Clarke KR (2007) Effects of demersal trawling on ecosystem functioning in the North Sea: a modelling study. Mar Ecol Prog Ser 336:63-75

Bates S, Deepayan S and the R Development Core Team (2013) nlme: Linear and nonlinear mixed effects models. $\mathrm{R}$ package version 3.1-113

Bertics VJ, Ziebis W (2009) Biodiversity of benthic microbial communities in bioturbated coastal sediments is controlled by geochemical microniches. ISME J 3:1269-1285

Bird FL, Ford PW, Hancock GJ (1999) Effect of burrowing macrobenthos on the flux of dissolved substances across the water-sediment interface. Mar Freshwater Res 50:523-532

Bolam SG, Coggan RC, Eggleton J, Diesing M, Stephens D (2014) Sensitivity of macrobenthic secondary production to trawling in the English sector of the Greater North Sea: a biological trait approach. J Sea Res 85:162-177

Braeckman U, Yazdani Foshtoni M, Van Gansbeke D, Meysman F, Soetaert K, Vincx M, Vanaverbeke J (2014) Variable importance of macrofaunal functional biodiversity for biogeochemical cycling in temperate coastal sediments. Ecosystems 17:720-737

Caffrey JM, Sloth NP, Kaspar HF, Blackburn TH (1993) Effect of organic loading on nitrification and denitrification in a marine sediment microcosm. FEMS Microbiol Ecol 12:159-167

Conley DJ, Johnstone RW (1995) Biogeochemistry of N, P and $\mathrm{Si}$ in Baltic Sea sediments: response to a simulated deposition of a spring diatom bloom. Mar Ecol Prog Ser 122:265-276
Dale AW, Prego R (2002) Physico-biogeochemical controls on benthic-pelagic coupling of nutrient fluxes and recycling in a coastal upwelling system. Mar Ecol Prog Ser 235:15-28

Dang H, Chen R, Wang L, Guo L, Chen P, Tang Z, Tian F, Li S, Klotz MG (2010) Environmental factors shape sediment anammox bacterial communities in hypernutrified Jiaozhou Bay, China. Appl Environ Microb 76:7036-7047

Duplisea DE, Jennings S, Malcolm SJ, Parker R, Sivyer DB (2001) Modelling potential impacts of bottom trawl fisheries on soft sediment biogeochemistry in the North Sea. Geochem Trans 2:112-117

Falcão M, Gaspar MB, Caetano M, Santos MN, Vale C (2003) Short-term environmental impact of clam dredging in coastal waters (south of Portugal): chemical disturbance and subsequent recovery of seabed. Mar Environ Res 56:649-664

Fanjul E, Grela MA, Iribarne O (2007) Effects of the dominant SW Atlantic intertidal burrowing crab Chasmagnathus granulatus on sediment chemistry and nutrient distribution. Mar Ecol Prog Ser 341:177-190

Fiordelmondo C, Manini E, Gambi C, Pusceddu A (2003) Shortterm impact of clam harvesting on sediment chemistry, benthic microbes and meiofauna in the Goro Lagoon (Italy). Chem Ecol 19:173-187

Franco MA, Mesel I, Demba Diallo M, Gucht VDK, Gansbeke VD, Van Rijswijk P, Costa MJ, Vincx M, Vanaverbeke J (2007) Effect of phytoplankton bloom deposition on benthic bacterial communities in two contrasting sediments in the southern North Sea. Aquat Microb Ecol 48:241-254

Gihring TM, Humphrys M, Mills HJ, Huettel M, Kostka JE (2009) Identification of phytodetritus-degrading microbial communities in sublittoral Gulf of Mexico sands. Limnol Oceanogr 54:1073-1083

Gilbertson WW, Solan M, Prosser JI (2012) Differential effects of microorganism-invertebrate interactions on benthic nitrogen cycling. FEMS Microb Ecol 82:11-22

Goldberg R, Rose JM, Mercaldo-Allen R, Meseck SL, Clark P, Kuropat C, Pereira JJ (2014) Effects of hydraulic dredging on the benthic ecology and sediment chemistry on a cultivated bed of the Northern quahog, Mercenaria mercenaria. Aquaculture 428:150-157

Hale R, Godbold JA, Sciberras M, Dwight J, Wood C, Hiddink JG, Solan M (2017) Mediation of macronutrients and carbon by post-disturbance shelf sea sediment communities. Biogeochemistry. doi:10.1007/s 10533-017-0350-9

Hiddink JG, Jennings S, Kaiser MJ, Queiros AM, Duplisea DE, Piet GJ (2006) Cumulative impacts of seabed trawl disturbance on benthic biomass, production, and species richness in different habitats. Can J Fish Aquat Sci 63:721-736

Hiddink JG, Davies TW, Perkins M, Machairopoulou M, Neill SP (2009) Context dependency of relationships between biodiversity and ecosystem functioning is different for multiple ecosystem functions. Oikos 118:1892-1900

Holme NA, McIntyre AD (1984) Methods for the study of marine benthos. Blackwell Scientific Publications, London

Howe RL, Rees AP, Widdicombe S (2004) The impact of two species of bioturbating shrimp (Callianassa subterranea and Upogebia deltaura) on sediment denitrification. J Mar Biol Assoc UK 84:629-632 
Kaiser MJ, Spencer BE (1996) The effects of beam trawl disturbance on infaunal communities in different habitats. J Anim Ecol 65:348-358

Kaiser MJ, Clarke KR, Hinz H, Austen MCV, Somerfield PJ, Karakassis I (2006) Global analysis of response and recovery of benthic biota to fishing. Mar Ecol Prog Ser 311:1-14

Kitidis V, Tait K, Nunes J, Brown I, Woodward EMS, Harris C, Sabadel AJM, Sivyer DB, Silburn B, Kröger S (2017) Seasonal benthic nitrogen cycling in a temperate Shelf Sea: the Celtic Sea. Biogeochemistry. doi:10.1007/s10533-0170311-3

Kristensen E, Penha-Lopes G, Delefosse M, Valdemarsen T, Quintana CO, Banta GT (2012) What is bioturbation? The need for a precise definition for fauna in aquatic sciences. Mar Ecol Prog Ser 446:285-302

Lambert GI, Jennings S, Kaiser MJ, Davies TW, Hiddink JG (2014) Quantifying recovery rates and resilience of seabed habitats impacted by bottom fishing. J Appl Ecol 51:1326-1336

Laverock B, Gilbert JA, Tait K, Osborn AM, Widdicombe S (2011) Bioturbation: impact on the marine nitrogen cycle. Biochem Soc Trans 39:315-320

Laverock B, Tait K, Gilbert JA, Osborn AM, Widdicombe S (2014) Impacts of bioturbation on temporal variation in bacterial and archaeal nitrogen-cycling gene abundance in coastal sediments. Environ Microb Rep 6:113-121

Levin L, Blair N, DeMaster D, Plaia G, Fornes W, Martin C, Thomas C (1997) Rapid subduction of organic matter by maldanid polychaetes on the North Carolina slope. J Mar Res 55:595-611

Lohrer AM, Thrush SF, Hunt L, Hancock N, Lundquist C (2005) Rapid reworking of subtidal sediments by burrowing spatangoid urchins. J Exp Mar Biol Ecol 321:155-169

Luna GM, Manini E, Danovaro R (2002) Large fraction of dead and inactive bacteria in coastal marine sediments: comparison of protocols for determination and ecological significance. Appl Environ Microb 68:3509-3513

MarLIN (2006). BIOTIC-biological traits information catalogue. Marine Life Information Network. Plymouth: Marine Biological Association of the United Kingdom. http://www.marlin.ac.uk/biotic. Accessed 03/07/2017

Mayer LM, Schick DF, Findlay R, Rice DL (1991) Effects of commercial dragging on sedimentary organic matter. Mar Environ Res 31:249-261

Mayor DJ, Thornton B, Zuur AF (2012) Resource quantity affects benthic microbial community structure and growth efficiency in a temperate intertidal mudflat. PLoS ONE $7: 1-6$

Mermillod-Blondin F, Rosenberg R (2006) Ecosystem engineering: the impact of bioturbation on biogeochemical processes in marine and freshwater benthic habitats. Aquat Sci 68:434-442

Mermillod-Blondin F, Rosenberg R, Francois-Carcaillet F, Norling K, Mauclaire L (2004) Influence of bioturbation by three benthic infaunal species on microbial communities and biogeochemical processes in marine sediment. Aquat Microb Ecol 36:271-284

Olsgard F, Schaanning MT, Widdicombe S, Kendall MA, Austen MC (2008) Effects of bottom trawling on ecosystem functioning. J Exp Mar Biol Ecol 366:123-133
Osinga R, Lewis WE, Wopereis JLM, Vriezen C, van Duyl FC (1995) Effects of the sea urchin Echinocardium cordatum on oxygen uptake and sulfate reduction in experimental benthic systems under increasing organic loading. Ophelia 41:221-236

Pilskaln CH, Churchill JH, Mayer LM (1998) Resuspension of sediment by bottom trawling in the Gulf of Maine and potential geochemical consequences. Conserv Biol 12:1223-1229

Pittman J, Armitage D (2016) Governance across the land-sea interface: a systematic review. Environ Sci Pol 64:9-17

Queiros AM, Birchenough SNR, Bremner J et al (2013) A bioturbation classification of European marine infaunal invertebrates. Ecol Evol 3:3958-3985

Quijón PA, Kelly MC, Snelgrove PVR (2008) The role of sinking phytodetritus in structuring shallow-water benthic communities. J Exp Mar Biol Ecol 366:134-145

R Development Core Team (2005) R: A language and environment for statistical computing, reference index version 2.2.1. R Foundation for Statistical Computing, Vienna, Austria. http://www.R-project.org

Rysgaard S, Risgaard-Petersen N, Sloth NP, Jensen K, Nielsen LP (1994) Oxygen regulation of nitrification and denitrification in sediments. Limnol Oceanogr 39:1643-1652

Sciberras M, Hinz H, Bennell JD, Jenkins SR, Hawkins SJ, Kaiser MJ (2013) Benthic community response to a scallop dredging closure within a dynamic seabed habitat. Mar Ecol Prog Ser 480:83-98

Sciberras M, Parker R, Powell C, Robertson C, Kroeger S, Bolam S, Hiddink JG (2016) Impacts of bottom fishing on the sediment infaunal community and biogeochemistry of cohesive and non-cohesive sediments. Limnol Oceangr. doi:10.1002/lno.10354

Small C, Nicholls RJ (2003) A global analysis of human settlement in coastal zones. J Coast Res 19:584-599

Solan M, Cardinale B, Downing AL, Engelhardt KAM, Ruesink JL, Srivastava DS (2004) Extinction and ecosystem function in the marine benthos. Science 12:1177-1180

Tait K, Airs RL, Widdicombe CE, Tarran GA, Jones MR, Wddicombe S (2015) Dynamic responses of the benthic bacterial community at the Western English Channel observatory site L4 are driven by deposition of fresh phytodetritus. Prog Oceanogr 137:546-558

Tillin HM, Hiddink JG, Jennings S, Kaiser MJ (2006) Chronic bottom trawling alters the functional composition of benthic invertebrate communities on a sea-basin scale. Mar Ecol Prog Ser 318:31-45

Trimmer M, Petersen J, Sivyer DB, Mills C, Young E, Parker ER (2005) Impact of long-term benthic trawl disturbance on sediment sorting and biogeochemistry in the southern North Sea. Mar Ecol Prog Ser 298:79-94

van Denderen PD, Bolam SG, Hiddink JG, Jennings S, Kenny A, Rijnsdorp AD, van Kooten $T$ (2015) Similar effects of bottom trawling and natural disturbance on composition and function of benthic communities across habitats. Mar Ecol Prog Ser 541:31-43

van Oevelen D, Soetaert K, Franco MA, Moodley L, van Ijzerloo L, Vincx M, Vanaverbeke J (2009) Organic matter input and processing in two contrasting North Sea sediments: insights from stable isotope and biomass data. Mar Ecol Prog Ser 380:19-32 
Voss M, Bange HW, Dippner JW, Middelburg JJ, Montoya JP, Ward B (2013) The marine nitrogen cycle: recent discoveries, uncertainties and the potential relevance of climate change. Philos T Roy Soc B 368:1-11

Warnken KW, Gill GA, Dellapenna TM, Lehman RD, Harper DE, Allison MA (2003) The effects of shrimp trawling on sediment oxygen consumption and the fluxes of trace metals and nutrients from estuarine sediments. Estuar Coast Shelf Sci 57:25-42

Watling L, Findlay RH, Mayer LM, Schick DF (2001) Impact of a scallop drag on the sediment chemistry, microbiota and faunal assemblages of a shallow subtidal marine benthic community. J Sea Res 46:309-324

Widdicombe S, Austen MC, Kendall MA, Olsgard F, Schaanning MT, Dashfield SL, Needham HR (2004) The importance of bioturbators for biodiversity maintenance: the indirect effect of fishing disturbance. Mar Ecol Prog Ser 275:1-10

Wohlgemuth D, Solan M, Godbold JA (2017) Species contributions to ecosystem process and function can be population dependent and modified by biotic and abiotic setting. Proc R Soc B 284:20162805

Zehr JP, Kudela RM (2011) Nitrogen cycle of the open ocean: from genes to ecosystems. Annu Rev Mar Sci 3:197-225

Zhang Q, Warwick RM, McNeill CL, Widdicombe CE, Sheehan A, Widdicombe S (2015) An unusually large phytoplankton spring bloom drives rapid changes in benthic diversity and ecosystem function. Prog Oceanogr 137:533-545

Zuur AF, Iena EN, Walker N, Saveliev AA, Smith GM (2009) Mixed effects models and extensions in ecology with R. Springer, New York 